Article

\title{
Synthesis and Characterisation of Novel Tricyclic and Tetracyclic Furoindoles: Biological Evaluation as SAHA Enhancer against Neuroblastoma and Breast Cancer Cells
}

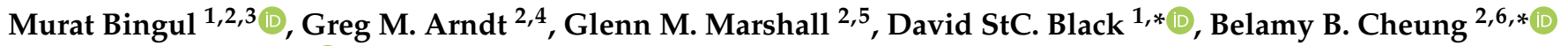 \\ and Naresh Kumar $1, *$ (D) \\ 1 School of Chemistry, The University of New South Wales, Sydney, NSW 2052, Australia; \\ muratbingul1983@gmail.com \\ 2 Lowy Cancer Research Centre, Children's Cancer Institute, UNSW Sydney, Sydney, NSW 2031, Australia; \\ GArndt@ccia.unsw.edu.au (G.M.A.); gmarshall@ccia.unsw.edu.au (G.M.M.) \\ 3 School of Pharmacy, Dicle University, Diyarbakır 21280, Turkey \\ 4 ACRF Drug Discovery Centre for Childhood Cancer, Children's Cancer Institute Australia for Medical \\ Research, Lowy Cancer Research Centre, UNSW Sydney, Sydney, NSW 2052, Australia \\ 5 Kids Cancer Centre, Sydney Children's Hospital, Randwick, NSW 2031, Australia \\ 6 School of Women's and Children's Health, UNSW Sydney, Sydney, NSW 2052, Australia \\ * Correspondence: d.black@unsw.edu.au (D.S.B.); bcheung@ccia.unsw.edu.au (B.B.C.); \\ n.kumar@unsw.edu.au (N.K.); Tel.: +61-2-9385-4657 (D.S.B.); +61-2-9385-2450 (B.B.C.); +61-2-9385-4698 (N.K.)
}

\section{check for} updates

Citation: Bingul, M.; Arndt, G.M.; Marshall, G.M.; Black, D.S.; Cheung, B.B.; Kumar, N. Synthesis and Characterisation of Novel Tricyclic and Tetracyclic Furoindoles: Biological Evaluation as SAHA Enhancer against Neuroblastoma and Breast Cancer Cells. Molecules 2021, 26, 5745. https://doi.org/10.3390/ molecules26195745

Academic Editor: René Csuk

Received: 10 August 2021

Accepted: 14 September 2021

Published: 22 September 2021

Publisher's Note: MDPI stays neutral with regard to jurisdictional claims in published maps and institutional affiliations.

Copyright: (c) 2021 by the authors. Licensee MDPI, Basel, Switzerland. This article is an open access article distributed under the terms and conditions of the Creative Commons Attribution (CC BY) license (https:/ / creativecommons.org/licenses/by/ $4.0 /)$.

\begin{abstract}
The dihydropyranoindole structures were previously identified as promising scaffolds for improving the anti-cancer activity of histone deacetylase inhibitors. This work describes the synthesis of related furoindoles and their ability to synergize with suberoylanilide hydroxamic acid (SAHA) against neuroblastoma and breast cancer cells. The nucleophilic substitution of hydroxyindole methyl esters with $\alpha$-haloketones yielded the corresponding arylether ketones, which were subsequently cyclized to tricyclic and tetracyclic furoindoles. The furoindoles showed promising individual cytotoxic efficiency against breast cancer cells, as well as decent SAHA enhancement against cancer cells in select cases. Interestingly, the best $\mathrm{IC}_{50}$ value was obtained with the non-cyclized intermediate.
\end{abstract}

Keywords: furoindole; SAHA enhancement; HDAC inhibitors; neuroblastoma; breast cancer

\section{Introduction}

Suberoylanilide hydroxamic acid (SAHA, also known as vorinostat) is an anticancer therapeutic agent due to its histone deacetylase (HDAC) inhibitory activity [1-3]. The inhibition of HDAC enzymes results in the accumulation of acetylated histones, which in turn leads to an increase in transcriptionally active chromatin [4,5]. HDAC inhibitors have been reported to suppress cell proliferation and angiogenesis, induce cell differentiation, and promote apoptosis in a number of cancer cell types [6,7]. Although SAHA has been approved for the treatment of cutaneous T-cell lymphoma as a monotherapy, it is still susceptible to resistance arising from mutation of cancer cells [8]. Moreover, as SAHA targets only one signalling pathway or molecular mechanism, single-agent treatment with SAHA was ineffective against several cancers $[9,10]$. Hence, the combination of SAHA with other chemotherapeutic agents with different mechanisms of action has been considered to be a promising approach to overcome resistance to single-agent therapies [9-11].

The starting point for this study was the screening of 10,560 compounds from the Walter and Eliza Hall Institute (WEHI) library to identify molecules that could act synergistically with SAHA to overcome drug resistance in SAHA-resistant MDA-MB-231 breast cancer cell lines [12]. By considering the structural features of the hit compounds, briefly tricyclic or tetracyclic nitrogen containing aromatic compounds, our previous study [13] investigated related heterocyclic molecules for activity against SH-SY5Y neuroblastoma 
and MDA-MB-231 breast cancer cell lines [14]. It was concluded that indole systems, and dihydropyranoindole derivatives in particular, were viable lead structures for the development of novel SAHA enhancers with low toxicity to normal cells.

The previous work also suggested that furo moieties could be promising targets for SAHA enhancers [13]. The main work in this manuscript describes the synthesis, characterization and in vitro biological evaluation of a series of tricyclic and tetracyclic furoindole derivatives. The effectiveness of the novel compounds as single agents and in combination with a clinical dose of SAHA was determined against neuroblastoma and breast cancer cells.

\section{Results and Discussion}

\subsection{Chemistry}

\subsubsection{Preparation of Hydroxy-Indole Methyl-2-Carboxylates}

In the current work, the targeted indoles were synthesized by the Hemetsberger indole synthesis [15] (Scheme 1). First, the substituted benzaldehydes 1-4 were reacted with benzyl bromide in the presence of potassium carbonate in acetone to afford the protected carbaldehydes 5-8 [16-19], respectively. The benzyl-protected carbaldehydes were condensed with methyl azidoacetate in the presence of sodium methoxide to obtain the azidoacrylate intermediates $\mathbf{9 - 1 2}[16,20,21]$. Thermal decomposition of the arylazido esters was performed by heating at reflux in xylene, generating the methyl indole-2-carboxylates 13-16 in good yields. Hydrogenolysis of the benzyl group was carried out by treating the compounds with $5 \% w / w$ palladium on carbon under a hydrogen atmosphere at room temperature, yielding the desired methyl 4,6-dihydroxyindole-2-carboxylate 17 [22], methyl 5,6-dihydroxyindole-2-carboxylate 18, methyl 5-hydroxy-6-methoxyindole-3-carboxylate 19 [23] and methyl 6-hydroxy-5-methoxyindole-2-carboxylate 20 [24].

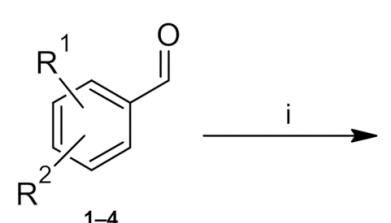

$1 \mathrm{R}^{1}=2-\mathrm{OH}, \mathrm{R}^{2}=4-\mathrm{OH}$

$2 \mathrm{R}^{1}=3-\mathrm{OH}, \mathrm{R}^{2}=4-\mathrm{OH}$

$3 \mathrm{R}^{1}=3-\mathrm{OH}, \mathrm{R}^{2}=4-\mathrm{OMe}$

$4 \mathrm{R}^{1}=3-\mathrm{OMe}, \mathrm{R}^{2}=4-\mathrm{OH}$

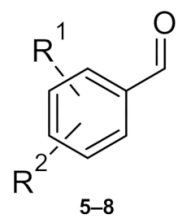

$5 \mathrm{R}^{1}=2-\mathrm{OBn}, \mathrm{R}^{2}=4-\mathrm{OBn}$

$6 \mathrm{R}^{1}=3-\mathrm{OBn}, \mathrm{R}^{2}=4-\mathrm{OBn}$

$7 \mathrm{R}^{1}=3-\mathrm{OBn}, \mathrm{R}^{2}=4-\mathrm{OMe}$

$8 \mathrm{R}^{1}=3-\mathrm{OMe}, \mathrm{R}^{2}=4-\mathrm{OBn}$

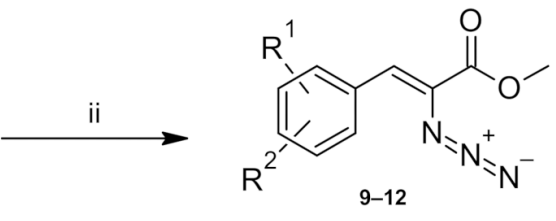

$9 \mathrm{R}^{1}=2-\mathrm{OBn}, \mathrm{R}^{2}=4-\mathrm{OBn}$ $10 R^{1}=3-O B n, R^{2}=4-O B n$ $11 \mathrm{R}^{1}=3-\mathrm{OBn}, \mathrm{R}^{2}=4-\mathrm{OMe}$ $12 \mathrm{R}^{1}=3-\mathrm{OMe}, \mathrm{R}^{2}=4-\mathrm{OBn}$

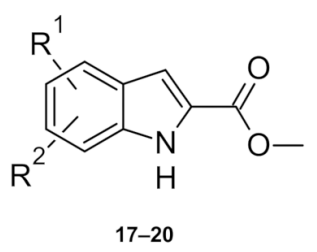

$17 \mathrm{R}^{1}=4-\mathrm{OH}, \mathrm{R}^{2}=6-\mathrm{OH}$

$18 \mathrm{R}^{1}=5-\mathrm{OH}, \mathrm{R}^{2}=6-\mathrm{OH}$

$19 \mathrm{R}^{1}=5-\mathrm{OH}, \mathrm{R}^{2}=6-\mathrm{OMe}$

$20 \mathrm{R}^{1}=5-\mathrm{OMe}, \mathrm{R}^{2}=6-\mathrm{OH}$ iii
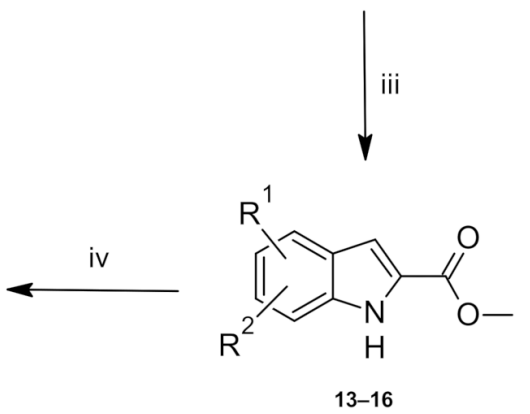

$13 \mathrm{R}^{1}=4-\mathrm{OBn}, \mathrm{R}^{2}=6-\mathrm{OBn}$ $14 \mathrm{R}^{1}=5-\mathrm{OBn}, \mathrm{R}^{2}=6-\mathrm{OBn}$ $15 \mathrm{R}^{1}=5-\mathrm{OBn}, \mathrm{R}^{2}=6-\mathrm{OMe}$ $16 \mathrm{R}^{1}=5-\mathrm{OMe}, \mathrm{R}^{2}=6-\mathrm{OBn}$

Scheme 1. Reagents and conditions: (i) benzyl bromide, $\mathrm{K}_{2} \mathrm{CO}_{3}$, DMF, reflux, overnight; (ii) methyl azidoacetate, $\mathrm{NaOMe}$, anhydrous $\mathrm{MeOH},<10{ }^{\circ} \mathrm{C}, 4 \mathrm{~h}$; (iii) xylene, reflux, $2 \mathrm{~h}$, (iv) $5 \% \mathrm{Pd} / \mathrm{C}, \mathrm{H}_{2}$, $\mathrm{MeOH} / \mathrm{THF}, 2 \mathrm{~h}$, rt. 
The ${ }^{1} \mathrm{H}-\mathrm{NMR}$ spectra of methyl 5-hydroxy-6-methoxyindole-2-carboxylate 19 and methyl 6-hydroxy-5-methoxyindole-2-carboxylate 20 in $\mathrm{CDCl}_{3}$ contained an identical number of signals differing in their splitting patterns and the resulting coupling constants. In the spectrum of compound 19, the $\mathrm{H} 4$ proton was observed as a doublet at $6.86 \mathrm{ppm}$, due to the coupling to neighbouring $\mathrm{OH}$ proton with a $0.9 \mathrm{~Hz}$ coupling constant. Furthermore, the $\mathrm{H} 7$ proton was observed as a singlet at $7.16 \mathrm{ppm}$. In the case of the compound 20, H7 resonated as a doublet at $6.96 \mathrm{ppm}$ with a $0.9 \mathrm{~Hz}$ coupling constant and $\mathrm{H} 4$ resonated as a singlet at $7.06 \mathrm{ppm}$. The $\mathrm{OH}$ proton resonated as a broad singlet at 5.57 and $5.99 \mathrm{ppm}$ in the spectra of compounds 19 and 20, respectively. Additionally, in the spectra of compounds 19 and 20, respectively, $\mathrm{H} 3$ was observed as doublets at 7.11 and $7.06 \mathrm{ppm}(J=2.1 \mathrm{~Hz}$ for both indoles) due to the coupling with the $\mathrm{NH}$ proton, while the $\mathrm{NH}$ group was observed at 8.77 and $8.86 \mathrm{ppm}$, in the spectra of compounds 19 and 20 , respectively. The obtained ${ }^{1} \mathrm{H}-\mathrm{NMR}$ data are consistent with the reference data $[23,24]$.

The ${ }^{1} \mathrm{H}$-NMR spectrum of methyl 4,6-dihydroxyindole-2-carboxylate 17 in $d_{6}$-DMSO showed two broad singlet resonances at 9.17 and $9.66 \mathrm{ppm}$ corresponding to the hydroxyl protons. The $\mathrm{H} 5$ and $\mathrm{H} 7$ resonances appeared as doublets of doublets signals at 6.00 and $6.26 \mathrm{ppm}$, respectively, with 2.3 and $0.9 \mathrm{~Hz}$ coupling constants arising from meta coupling to each other as well as coupling with the hydroxy groups. Similarly, in the ${ }^{1} \mathrm{H}-\mathrm{NMR}$ spectrum of methyl 5,6-dihydroxyindole-2-carboxylate 18 in $d_{6}$-DMSO, the hydroxy protons were observed as broad singlets at 8.84 and $9.17 \mathrm{ppm}$, while the $\mathrm{H} 4$ and $\mathrm{H7}$ protons resonated as doublets at 6.79 and $6.90 \mathrm{ppm}$ with a coupling constant of $0.8 \mathrm{~Hz}$ due to coupling with the nearby hydroxy groups. The followed synthetic strategy was applied for the first time to produce the compound 18.

\subsubsection{Synthesis of Furo [2,3-G]indoles and Furo [3,2-E]indoles via Methyl}

5-Hydroxy-6-Methoxy and 6-Hydroxy-5-Methoxyindole-2-Carboxylates

Following the successful preparation of the indole precursors, the tricyclic furoindole systems were targeted. Methyl 5-hydroxy-6-methoxyindole-3-carboxylate 19 and methyl 6-hydroxy-5-methoxyindole-2-carboxylate 20 were refluxed with chloroacetone in acetone in the presence of potassium carbonate to afford intermediates 21 and 23, respectively (Scheme 2). Intermediates 22 and $\mathbf{2 4}$ were prepared in a similar manner using 3-chloro-2butanone, and were obtained.

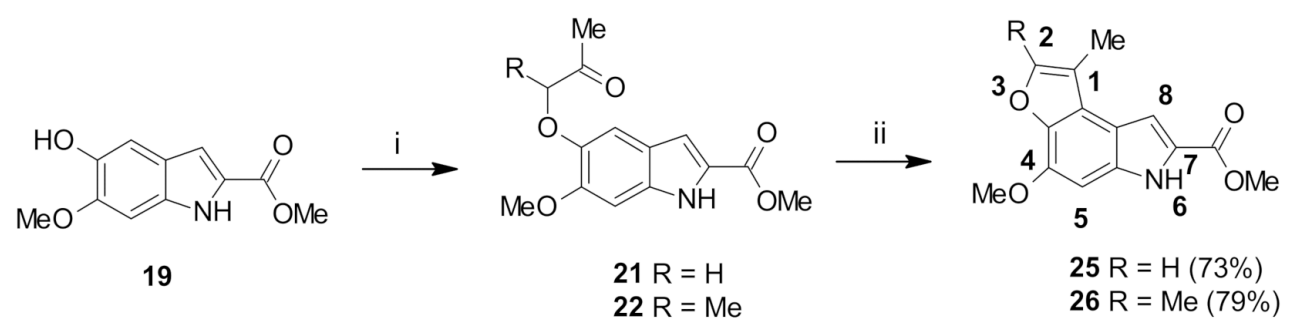

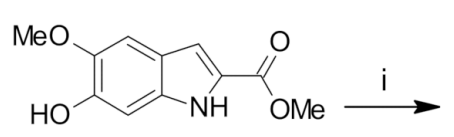

20
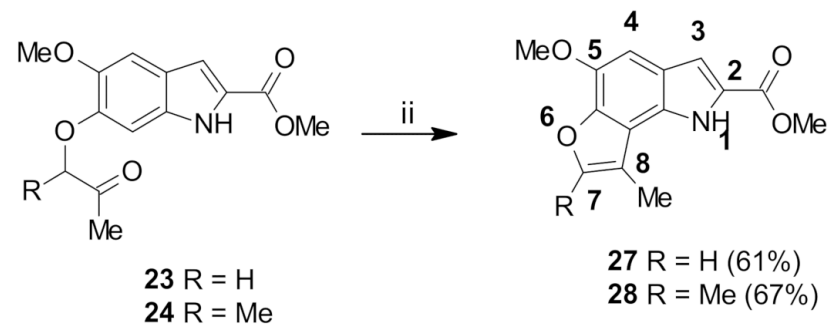

Scheme 2. Reagents and conditions: (i): chloroacetone or 3-chloro-2-butanone, acetone, $\mathrm{K}_{2} \mathrm{CO}_{3}$, reflux, overnight; 21 (81\%), 22 (85\%), 23 (78\%) and 24 (81\%) (ii): DCM, TFA, reflux overnight.

The ${ }^{1} \mathrm{H}-\mathrm{NMR}$ spectra of compounds 21 and 23 displayed singlet resonances corresponding to the $\alpha-\mathrm{CH}_{2}$ protons at 4.65 and $4.64 \mathrm{ppm}$, respectively. For 21, H7 and H4 were observed as doublets at 6.91 and $7.11 \mathrm{ppm}(J=0.9 \mathrm{~Hz})$, respectively, while for $23, \mathrm{H} 4$ and 
H7 appeared as two doublet signals at 6.80 and $7.13 \mathrm{ppm}(J=0.7 \mathrm{~Hz})$, respectively. Peaks corresponding to the $\mathrm{COCH}_{3}$ group were observed as singlets at 2.34 and $2.33 \mathrm{ppm}$ for intermediates 21 and 23, respectively. Further confirmation of the presence of the methylene group was provided by negative peaks at 74.9 and $74.5 \mathrm{ppm}$ in the DEPT-135 spectra of compounds 21 and 23, respectively. The ${ }^{1} \mathrm{H}-\mathrm{NMR}$ spectra of the intermediates 22 and 24 displayed similar signals in the aromatic region and for the $\mathrm{COCH}_{3}$ group. However, the $\alpha-\mathrm{CH}$ proton appeared as quartets at 4.57 and $4.63 \mathrm{ppm}(J=6.9 \mathrm{~Hz})$ for compounds 22 and 24, respectively, while additional doublets at 1.56 and $1.58 \mathrm{ppm}$ corresponding to the $\mathrm{CH}-\mathrm{CH}_{3}$ protons were also observed for 22 and 24, respectively.

Cyclization was performed by heating the intermediates 21-24 in DCM, using catalytic amounts of TFA. This afforded the novel tricyclic furo [2,3-g]indoles 25, 26 and furo [3,2e]indoles 27, 28 (Scheme 2). Cyclization was confirmed by comparison of the ${ }^{1} \mathrm{H}-\mathrm{NMR}$ spectra of the cyclic molecules 25-28 with the acyclic precursors 21-24. Cyclization of 21-24 to 25-28 was confirmed by the disappearance of H4 peak (for 25 and 26) and of H7 peak (for 27 and 28). Besides, singlet peak for $\alpha-\mathrm{CH} 2$ in 21 and 23 disappeared and were replaced by a new doublet signal at 7.51 and $7.49 \mathrm{ppm}$ in the cyclized products 25 and 27 , respectively. The splitting of these peaks was rationalized as being due to coupling between the $\mathrm{H} 2$ proton and the $\mathrm{C} 1$ methyl group on the furan ring. Cyclization of $\mathbf{2 2}$ and $\mathbf{2 4}$ was analogously demonstrated by the disappearance of the $\alpha-\mathrm{CH}$ multiplet in the spectra of the corresponding products $\mathbf{2 6}$ and $\mathbf{2 8}$.

\subsubsection{Synthesis of Difuro [2,3-e:2', 3'-G]indoles via Methyl}

4,6-Dihydroxyindole-2-Carboxylate

Due to the successful preparation of the tricyclic furoindole system, it was envisaged that this synthetic route would be applicable to the preparation of furoindole systems [25]. The interesting tetracyclic furoindoles were attempted to be synthesized via the treatment of methyl dihydroxyindole-2-carboxylate 17 with two equivalents of $\alpha$-haloketones. The nucleophilic substitution reaction of methyl 4,6-dihydroxyindole-2-carboxylate 17 with chloroacetone proceeded rapidly in the presence of potassium carbonate to form the dialkoxy derivative intermediate 29 in $82 \%$ yield (Scheme 3). Similarly, when compound 17 was condensed with 3-chloro-2-butanone under the same conditions, the desired intermediate 30 was formed as a white solid in an excellent yield of $88 \%$.
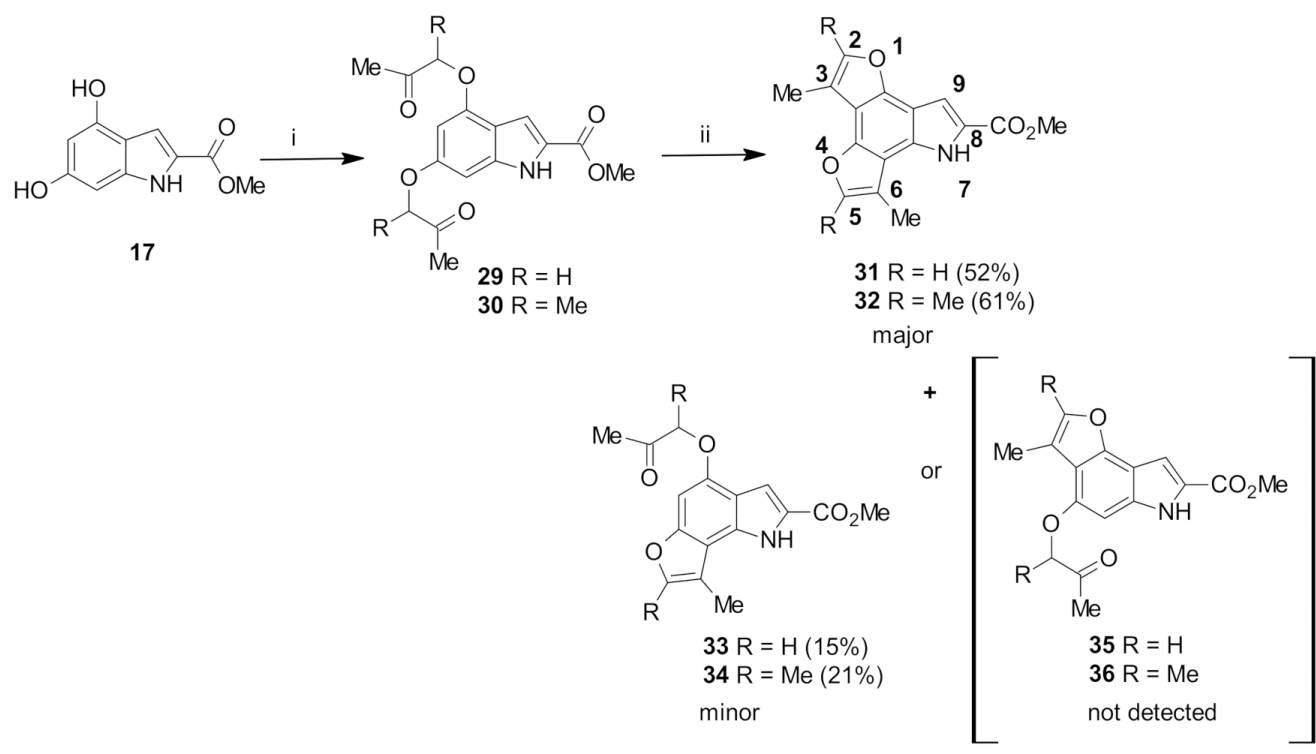

Scheme 3. Reagents and conditions: (i): chloroacetone or 3-chloro-2-butanone, acetone, $\mathrm{K}_{2} \mathrm{CO}_{3}$, reflux overnight, 29 (82\%) and 30 (88\%); (ii): DCM, TFA, reflux overnight. 
The ${ }^{1} \mathrm{H}-\mathrm{NMR}$ spectrum of intermediate 29 showed the presence of the $\alpha-\mathrm{CH}_{2}$ protons as singlets at 4.59 and $4.67 \mathrm{ppm}$, together with two singlets at $2.33 \mathrm{pm}$ and $2.39 \mathrm{ppm}$ corresponding to the $\mathrm{COCH}_{3}$ protons. $\mathrm{H} 5$ and $\mathrm{H} 7$ appeared as doublet at $6.28 \mathrm{ppm}$ and $6.37 \mathrm{ppm}$, respectively $(J=1.7 \mathrm{~Hz})$, due to meta coupling with each other. Meanwhile, the most significant feature in the ${ }^{1} \mathrm{H}-\mathrm{NMR}$ spectrum of compound 30 were two quartet signals at 4.55 and $4.78 \mathrm{ppm}$, corresponding to the two $\alpha-\mathrm{CH}$ protons, with $J=6.9 \mathrm{~Hz}$ due to coupling to the neighbouring $\mathrm{CH}_{3}$ protons. The $\mathrm{CH}-\mathrm{CH}_{3}$ protons appeared as doublets at $1.52 \mathrm{ppm}$ and $1.59 \mathrm{ppm}$, with the same coupling constant. Two singlet signals were observed at 2.16 and $2.24 \mathrm{ppm}$, which corresponded to the $\mathrm{COCH}_{3}$ protons.

When the acid-catalysed cyclization of ethers $\mathbf{2 9}$ and $\mathbf{3 0}$ was attempted, the reactions yielded two products (Scheme 3). After separation of the product mixtures by chromatography, the major products were identified as the desired tetracyclic compounds $\mathbf{3 1}$ and $\mathbf{3 2}$. The minor products appeared more polar than 31 and 32 by TLC analysis, so they were presumed to be the products arising from only one cyclization reaction. Spectroscopic analysis showed that the C7-cyclized compounds 33 and $\mathbf{3 4}$ had formed, rather than the C5-cyclized compounds 35 and 36.

The formation of the desired tetracyclic system 31 was confirmed by comparison of the ${ }^{1} \mathrm{H}-\mathrm{NMR}$ spectrum with that of the intermediate 29 . The absence of the doublet signals corresponding to $\mathrm{H} 5$ and $\mathrm{H} 7$ showed that cyclization reactions occurred at both positions on the benzene ring. Additional evidence was provided by the presence of doublets at $7.43 \mathrm{pm}$ and $7.48 \mathrm{ppm}$, corresponding to $\mathrm{H} 5$ and $\mathrm{H} 2$ of the new polycyclic systems. Similarly, in the ${ }^{1} \mathrm{H}-\mathrm{NMR}$ spectrum of 32 , the cyclization of both methyl ketones was confirmed by the absence of the two quartet signals assigned to the two $\alpha-\mathrm{CH}$ protons as well as the two doublet signals corresponding to $\mathrm{H} 5$ and H7. The H9 proton, appearing as a doublet due to the coupling with the neighbouring $\mathrm{NH}$ proton, appeared at $9.09 \mathrm{ppm}$ (Scheme 3).

Monocyclization was confirmed by ${ }^{13} \mathrm{C}-\mathrm{NMR}$ spectroscopy, which displayed only one characteristic methyl ketone carbon signal at 207.9 and $210.6 \mathrm{ppm}$ in the spectra of compounds 33 and 34, respectively. Similarly, the ${ }^{1} \mathrm{H}-\mathrm{NMR}$ spectrum of 33 showed only one singlet at $4.69 \mathrm{ppm}$, assigned to the $\alpha-\mathrm{CH}_{2}$ protons, and the spectrum for 30 showed only one quartet at $4.77 \mathrm{ppm}$, assigned to the $\alpha-\mathrm{CH}$ proton. It was also observed that one aromatic proton (H7) on the indole benzene ring was still present, appearing as a singlet signal due to the disappearance of meta coupling with the other aromatic proton (H5).

Determining the regiochemistry of cyclization required 2D NMR spectroscopic analysis. In compound 34 (b), the H-H NOESY spectrum (a) showed a through-space correlation between the NH group (9.05 ppm) with one of the two methyl groups on the furan ring $(2.40 \mathrm{ppm})($ showed in Figure 1b). This interaction would not be possible if cyclization had occurred at C5 instead. A similar 2D NMR pattern was observed in the case of the minor product formed from 29, thus confirming its actual structure to be the C7-cyclized compound 33. These results are consistent with previous findings that $\mathrm{C} 7$ is the most reactive position in methyl 4,6-disubstituted-2-carboxylates [26].

2.1.4. Attempted Synthesis of Difuro [3,2-e:2', 3'-G]indoles with a Different Heterocycles Orien-Tation

In order to prepare difuroindoles with different heterocyclic orientations, the previously developed strategy was applied to the 5,6-dihydroxyindole 18 core. The reaction of 18 with two equivalents of $\alpha$-haloketones (chloroacetone and 3-chloro-2-butanone) in the presence of $\mathrm{K}_{2} \mathrm{CO}_{3}$ generated two major products as the di-alkylated intermediates 37 and 38 as testified by the disappearing of both the $\mathrm{OH}$ signals (Scheme 4), while two singlets corresponding to the $\alpha-\mathrm{CH}_{2}$ protons at 4.59 and $4.67 \mathrm{ppm}$ and an overlapping singlet corresponding to the two $\mathrm{CH}_{3}$ groups at $2.36 \mathrm{ppm}$ appeared. The presence of methylene peaks at 74.4 and $74.9 \mathrm{ppm}$ in the DEPT- 135 spectrum further confirmed the structure of 37. In the case of 38 , multiplet signals in the range of $1.51-1.57 \mathrm{ppm}$, corresponding to the two 
$\mathrm{CH}-\mathrm{CH}_{3}$ protons, and multiplet signals between 4.60 and $4.69 \mathrm{ppm}$, assigned to the $\alpha-\mathrm{CH}$ protons, confirmed the double alkylation of the dihydroxyindole core.

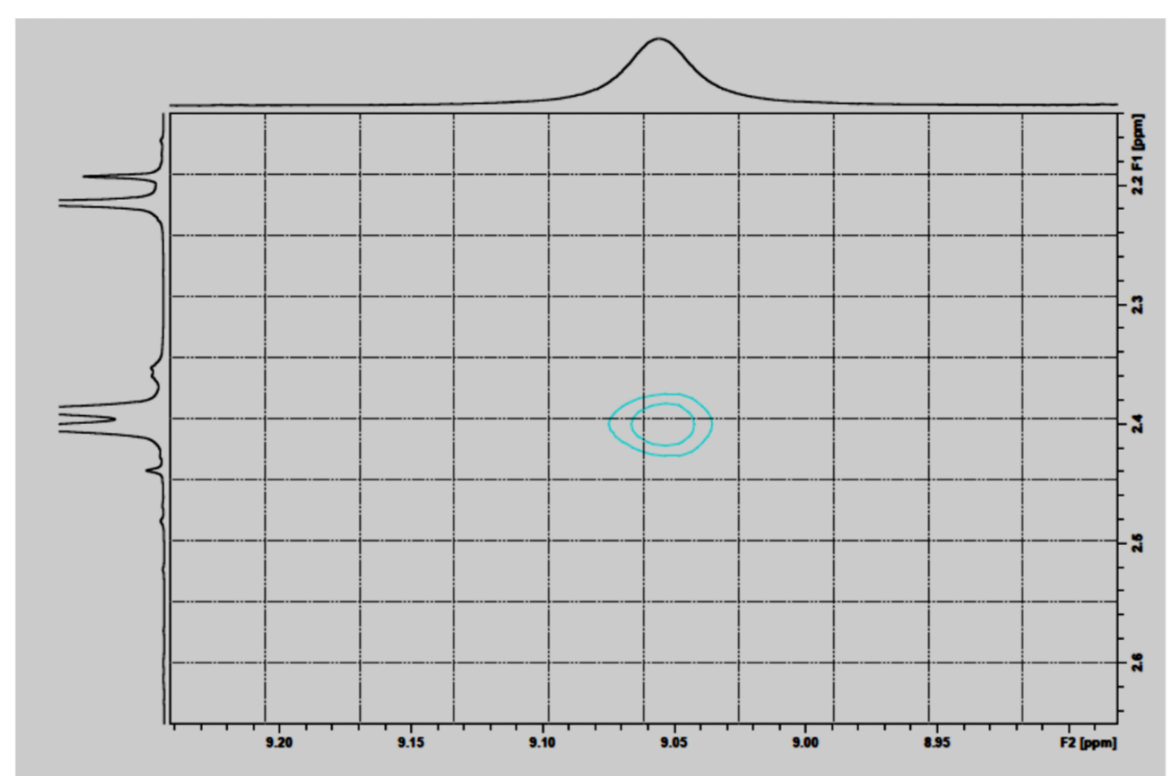

(a)<smiles>CC(=O)c1cc2c(OC(C)C(C)=O)cc3oc(C)c(C)c3c2[nH]1</smiles>

(b)

Figure 1. H-H NOESY NMR spectrum of compound 34 obtained by mono-cyclization of 30.

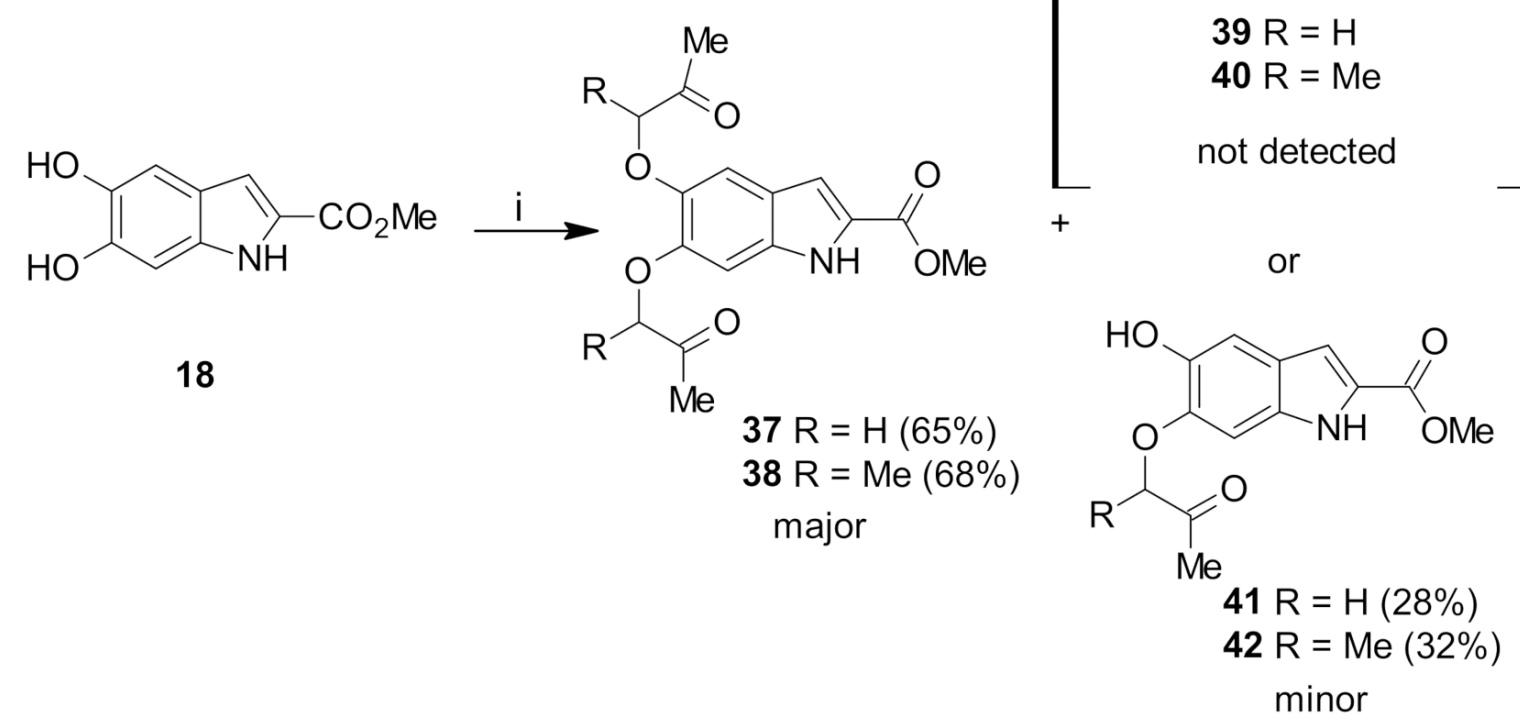

Scheme 4. Reagents and conditions: (i): chloroacetone or 3-chloro-2-butanone, acetone, $\mathrm{K}_{2} \mathrm{CO}_{3}$, reflux overnight. 
The minor products were the O-C6 mono-alkylated intermediates 41 and 42 . The ${ }^{1} \mathrm{H}$ NMR spectra of the mono-alkylated products in $\mathrm{CDCl}_{3}$ showed broad singlets at 5.26 and $5.61 \mathrm{ppm}$, indicating the presence of a hydroxyl group in each molecule. The characteristic singlet of the $\alpha-\mathrm{CH}_{2}$ protons at $4.67 \mathrm{ppm}$ and the multiplet of the $\alpha-\mathrm{CH}$ proton in the range of 4.02 to $4.09 \mathrm{ppm}$ matched the integrations expected for the mono-alkylated products. However, ${ }^{1} \mathrm{H}$-NMR spectroscopy was unable to assign the regiochemistry of the reaction. Instead, X-ray crystallography of a product obtained from a further stage (see below) established that HO-C6 substitution had occurred to give $\mathbf{4 1}$ and 42. It is proposed that in the nucleophilic substitution reaction $\mathrm{C} 6$ anion is formed more easily as a result of stabilization by the conjugated COOMe group.

Attempts to cyclize the intermediate ethers 37 and 38 in the same manner as for 29 and 30 using a catalytic amount of trifluoroacetic acid in dichloromethane resulted in the recovery of unconsumed starting materials (Scheme 4). Cyclization under more strongly acidic conditions, using a 1:1 ratio of solvent mixture (TFA and DCM) and neat acid, resulted in decomposition and the formation of polymerized products. Similar results were observed for the mono-alkylated intermediate 41, with a catalytic amount of trifluoroacetic acid giving unreacted starting materials, while more acidic conditions resulted in its decomposition. It is assumed that, while the 4,6-dihydroxy scaffold strongly increases the nucleophilicity of the $\mathrm{C} 5$ and $\mathrm{C} 7$ through resonance contribution and the cyclization occurs to produce the tetracyclic system. In the case of 5,6-dihydroxy system, the hydroxyl groups interfere with each other preventing the cyclization.

With mono-alkylated intermediate $\mathbf{4 2}$, cyclization using catalytic trifluoroacetic acid also led to no reaction. However, treatment of 42 using a 1:1 mixture of TFA and DCM afforded a single product 43 with an intense yellow colour in $64 \%$ yield (Scheme 5 ). The ${ }^{13} \mathrm{C}-\mathrm{NMR}$ spectrum of the product $\mathbf{4 3}$ showed the disappearance of the ketone carbonyl signal at $205.3 \mathrm{ppm}$, suggesting that cyclization had occurred. However, the appearance of only one aromatic proton signal (the indole H3) in the ${ }^{1} \mathrm{H}-\mathrm{NMR}$ spectrum, as well as the downfield shift of the single hydroxyl proton signal to $13.44 \mathrm{ppm}$, possibly due to strong hydrogen bonding, suggested that a substitution reaction had also occurred at the C4 position.<smiles>COC(=O)c1cc2cc(O)c(OC(C)C(C)=O)cc2[nH]1</smiles>

42

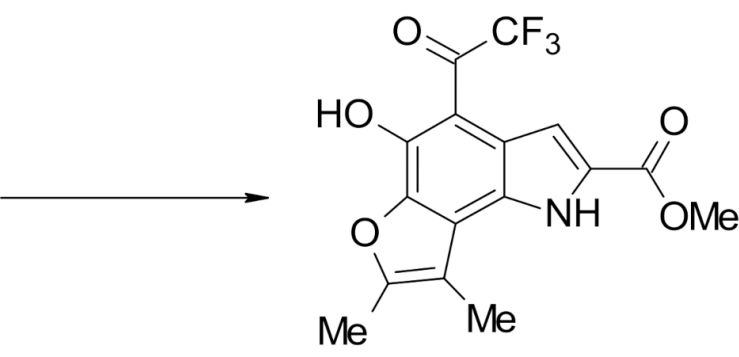

43

Scheme 5. Reagents and conditions: DCM, TFA, reflux overnight $43(64 \%)$.

The exact structure of compound $\mathbf{4 3}$ was revealed by $\mathrm{X}$-ray crystallographic analysis. It showed that an electrophilic substitution reaction had occurred at the $\mathrm{C} 4$ position with trifluoroacetic acid to generate the trifluoroacetyl-substituted furoindole. The crystal structure also revealed the presence of a hydrogen bond between the C 5 hydroxyl proton and C4 trifluoroacetyl carbonyl oxygen atom, which would account for the downfield shift of the $\mathrm{OH}$ signal in the ${ }^{1} \mathrm{H}-\mathrm{NMR}$ spectrum of $\mathbf{4 3}$ (Figure 2). The yellow colour in the Figure 2 demonstrates the $\mathrm{F}$ atoms. The red colour indicates the $\mathrm{O}$ atoms and blue line proves the hydrogen bonds occurring between the hydroxyl group and the carbonyl oxygen located at the 4-position. 


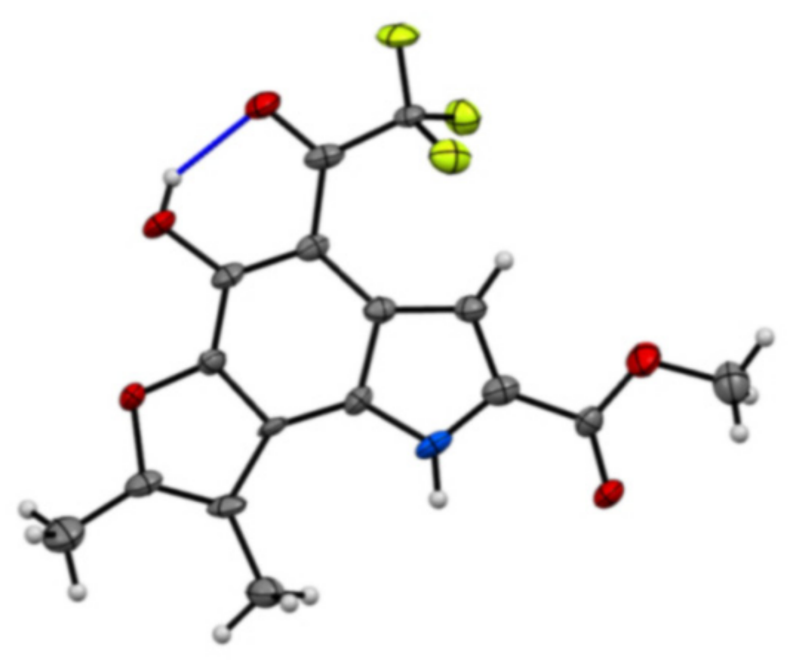

Figure 2. ORTEP diagram of compound 43.

In summary, the C6-hydroxy group in the 5,6-dihydroxyindole scaffold 18 was more acidic than the C5-hydroxy group, leading to the generation of the O-C6-alkylated indole. Both the mono-alkylated and di-alkylated intermediates were unreactive to cyclization using catalytic TFA, while more strongly acidic conditions led to decomposition. The only exception was methyl 5-methoxy-6-hydroxyindole-2-carboxylate 42 , which could be cyclized at $\mathrm{C} 7$ with concomitant substitution of a trifluoroacetyl group at $\mathrm{C} 4$ by using a 1:1 mixture of TFA and DCM, giving tricyclic compound $\mathbf{4 3}$ whose structure was confirmed by X-ray crystallographic analysis.

\subsection{Biological Results}

2.2.1. Preliminary Biological Screening of Furoindoles for SAHA Enhancement Activity

The ability of selected furoindoles (Figure 3) to enhance the activity of SAHA against the SH-SY5Y and Kelly neuroblastoma and MDA-MB-231 and MCF-7 breast adenocarcinoma cell lines was examined using the Alamar blue (Resazurin) assay [14].<smiles>COC(=O)c1cc2[nH]c3cc(OC)c(oc([14CH3])c2[14CH3])c13</smiles>

25<smiles>COC(=O)c1cc2cc(OC)c3oc4c(c3c2[nH]1)=C([N+](=O)[O-])C=4[N+](=O)[O-]</smiles>

27<smiles>COC(=O)c1cc2c(cc(OC)c3oc(C)c(C)c32)[nH]1</smiles>

26<smiles>COC(=O)c1cc2cc(OC)c3oc(C)c([N+](=O)[O-])c3c2[nH]1</smiles>

28<smiles>COC(=O)c1cc2c([nH]1)-c1c(C)[nH]c(c1C)Oc1c-2oc(C)c1C</smiles>

31<smiles>COC(=O)c1cc2c([nH]1)c1c(C)c(C)oc1c1c(C)c(C)oc21</smiles>

32<smiles>COC(=O)c1cc2c(C(F)(F)F)c(O)c3oc(C)c(C)c3c2[nH]1</smiles>

43

Figure 3. Tested furoindoles analogues against the panel of cancer cells. 
Cell lines were treated with $1 \mu \mathrm{M}$ SAHA (SH-SY5Y) and $0.5 \mu \mathrm{M}$ SAHA (Kelly), $10 \mu \mathrm{M}$ of the compounds, or their combination over $72 \mathrm{~h}$, and cell viabilities were normalized to a DMSO control. The furoindole compounds generally showed moderate cytotoxic activity against both neuroblastoma cell lines. The furoindoles $\mathbf{2 6}$ and $\mathbf{2 5}$ were the most cytotoxic against Kelly cells with $37 \%$ and $36 \%$ reduction in cell viability versus DMSO (Figure 4A). However, the compounds did not potentiate the cytotoxic effect of SAHA against Kelly cells. In the case of SH-SY5Y cells, compounds 31 and 32 were the most potent with $45 \%$ and $35 \%$ inhibition of cell viability, respectively, versus DMSO (Figure 4B). Importantly, all the furoindoles enhanced the SAHA activity towards the SH-SY5Y cells with reductions in cell viability values ranging from $7-29 \%$. The greatest SAHA enhancement was achieved by compound 43 , where the combination decreased SH-SY5Y cell viability (41\%) by a further $29 \%$ compared to SAHA alone (70\%).

\section{KELLY/72h}

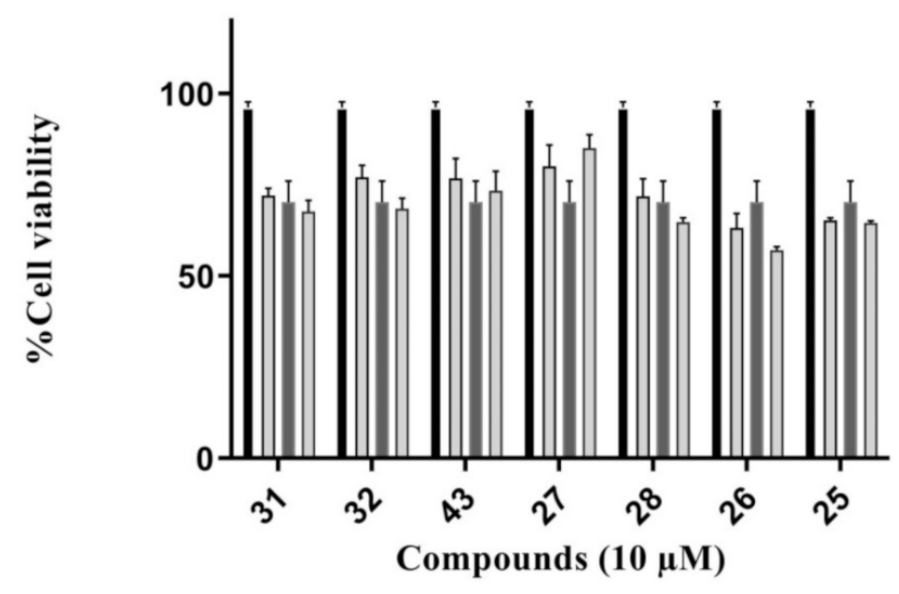

- Untreated control (DMSO)

$\square$ Compound

$0.5 \mu \mathrm{M}$ SAHA

$\square$ Compound+SAHA

(A)

SH-SY5Y/72h

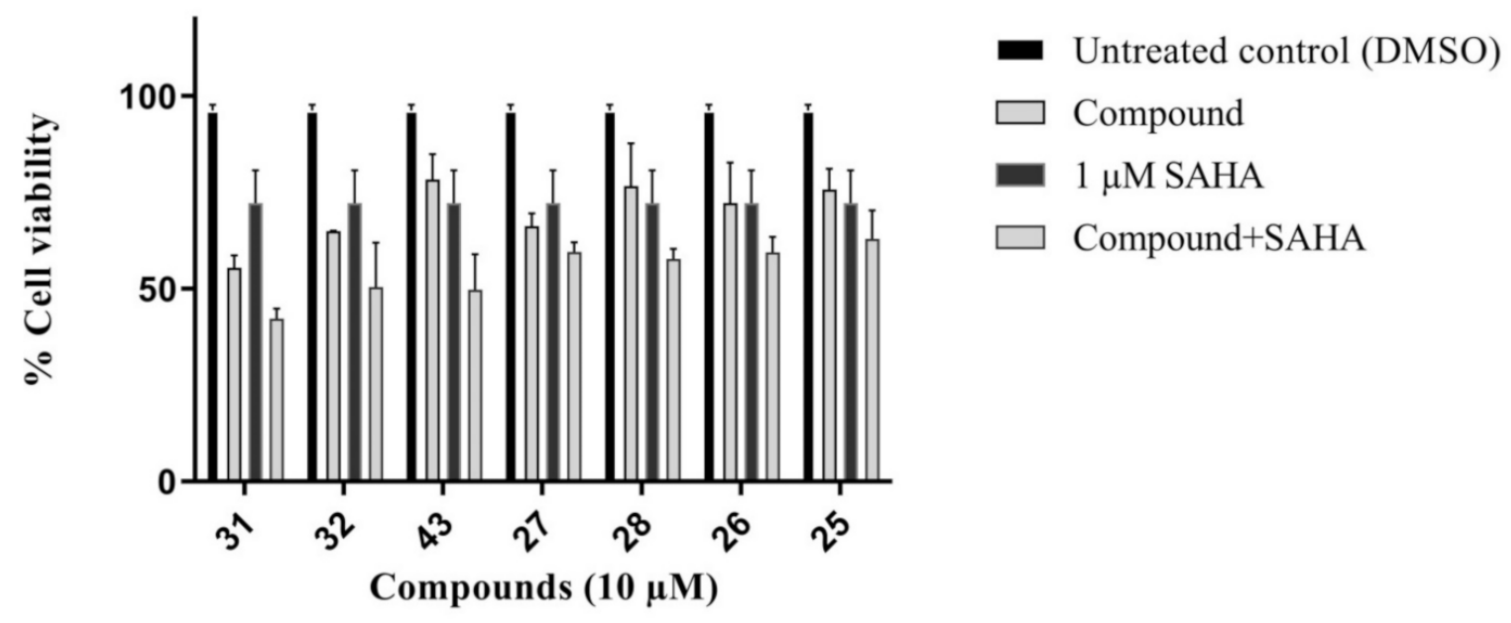

(B)

Figure 4. Cell viability of (A) KELLY (B) SH-SY5Y neuroblastoma cancer cells treated with $10 \mu \mathrm{M}$ compounds over $72 \mathrm{~h}$, in the presence or absence of $1 \mu \mathrm{M}$ of SAHA. Error bars represent mean values ( \pm S.D.) from three independent determinations. 
Against breast cancer cells, the furoindoles were more potent against the MDA-MB231 cell line (Figure 5A). Furoindoles $\mathbf{3 1}$ and $\mathbf{3 2}$ displayed the highest activity against MDA-MB-231 cells with inhibition values of $34 \%$ and $31 \%$, respectively. However, the compounds were less effective against MCF-7 cells, with viability being decreased by less than $10 \%$ for all compounds (Figure 5B). MCF-7 was determined as resistant cell line for SAHA alone treatment. The combination therapy also did not show enhancement activity.

MDA-MB-231/72h

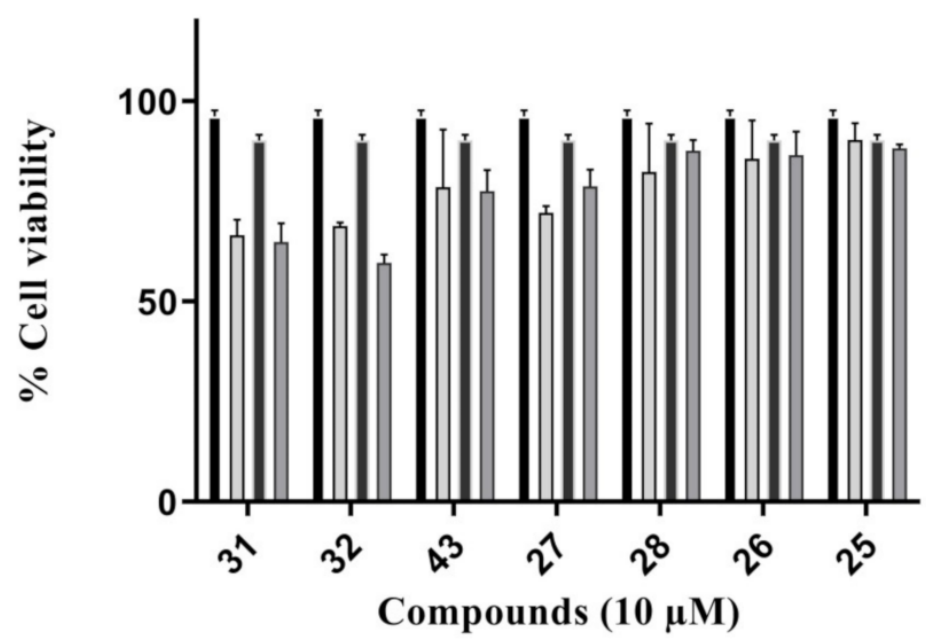

- Untreated control (DMSO)

$\square$ Compound

- $1 \mu \mathrm{M}$ SAHA

$\square$ Compound + SAHA

(A)

MCF-7/ 72h

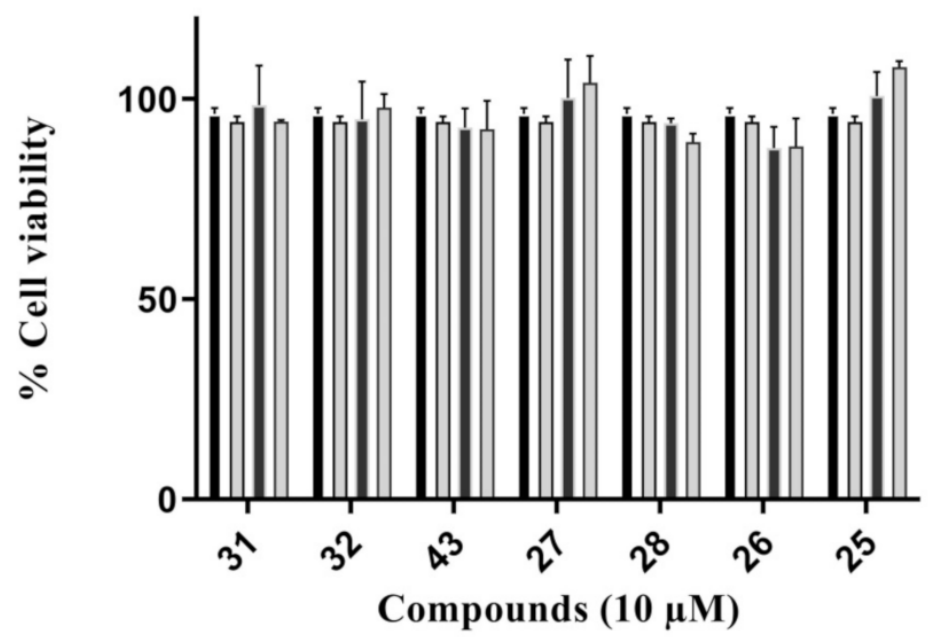

- Untreated control (DMSO)

$\square$ Compound

- $1 \mu \mathrm{M}$ SAHA

$\square$ Compound+SAHA

(B)

Figure 5. Cell viability of (A) MDA-MB-231 and (B) MCF-7 breast cancer cells treated with $10 \mu \mathrm{M}$ compounds over $72 \mathrm{~h}$, in the presence or absence of $1 \mu \mathrm{M}$ of SAHA. Error bars represent mean values $( \pm$ S.D.) for three independent determinations.

\subsubsection{SAR Study of Furoindoles}

Initial structure-activity relationship (SAR) analysis revealed that tetracyclic furoindoles (31-32) were more potent than the tricyclic furoindoles $(25-28,43)$ against MDA-MB231 and SH-SY5Y cells, although both classes showed similar cytotoxicity against MCF-7 and Kelly cells. Compound 31, a tetracyclic furoindole bearing a single methyl substituent on both furo rings and the dimethyl substituted analogue 32 showed comparable reduction of cell viability against SH-SY5Y cells with the values of 35\% and $30 \%$, respectively 
(Figure 4B). Compounds 31 and 32 also showed good cytotoxicity against the MDA-MB231 cell line with $35 \%$ and $32 \%$ reduction of cell viability, respectively (Figure 5A). This suggests that having a second furo ring fused to the indole moiety is beneficial for cytotoxic activity against MDA-MB-231 and SH-SY5Y cells.

The tricyclic furoindoles with a methoxy substituent on the indole benzene ring (2528) showed more cytotoxic potency against neuroblastoma cancer cells than against the breast cancer cells. Furo[3,2-e]indoles $\mathbf{2 6}$ and $\mathbf{2 5}$ demonstrated similar levels of cytotoxicity against SH-SY5Y cells with inhibition values of $29 \%$ and $25 \%$, respectively (Figure 4B), while against Kelly cells the inhibition values increased to 37\% and 35\% (Figure 4A). Furo[2,3$g$ ]indoles $\mathbf{2 7}$ and $\mathbf{2 8}$ were found to be as efficient as furo[3,2-e]indoles. Compound 27 displayed the highest reduction value of 33\% against SH-SY5Y cells and 29\% against Kelly cells, while compound 28 inhibited SH-SY5Y and Kelly cells by $23 \%$ and $31 \%$, respectively. Moreover, the two compounds showed different activity against MDA-MB-231 cells, with the monomethyl-substituted furoindole 27 ( $28 \%$ inhibition) being more potent than the dimethyl-substituted furoindole 28 (15\% inhibition) (Figure 5A). This suggests that the number of methyl groups might modulate the cytototoxic activity of these compounds against certain cell lines. Interestingly, replacement of the methoxy group with a hydroxy substituent and including an additional trifluoromethyl group on the indole benzene ring (43) increased the activity of SAHA against the SH-SY5Y cells by $29 \%$ compared to SAHA alone $(70 \%)$. The individual treatment of 43 provided $32 \%$ inhibition of the same cell line.

None of the tetracyclic or tricyclic compounds reduced MCF-7 cell viability by more than $10 \%$, suggesting that those cells were the most resistant against the furoindole systems, the same as the SAHA (Figure 5B).

\subsubsection{Investigation of Toxicity Levels of Non-Cyclized Intermediate 30, Tricyclic} Furoindole 34 and Tetracylic Furoindole 32 against the Neuroblastoma Cells

Having confirmed the promising cytotoxic activity of tetracyclic furoindoles $\mathbf{3 1}$ and 32 against neuroblastoma cells, it was anticipated that the non-cyclized intermediate $\mathbf{3 0}$ and mono-cyclized tricyclic furoindole 34 (Figure 6) might also show cytotoxic efficiency against neuroblastoma cells.

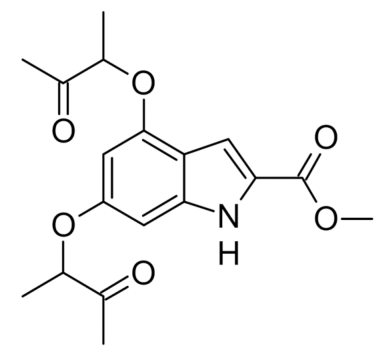

30

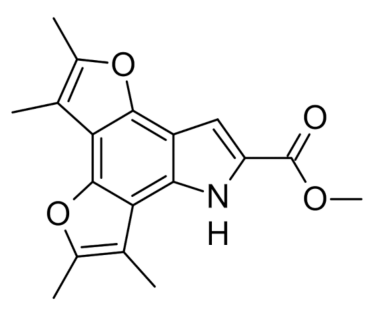

32<smiles>COC(=O)c1cc2c(OC(C)C(C)=O)cc3oc(C)c(C)c3c2[nH]1</smiles>

34

Figure 6. Compounds 30, 32 and 34 against neuroblastoma cells.

The $\mathrm{IC}_{50}$ values of furoindoles 30, 32 and 34 against SH-SY5Y and Kelly cells were determined using the Alamar blue (Resazurin) assay, at concentrations of 0.01, 0.1, 1, 10 , and $20 \mu \mathrm{M}$. The results showed that the non-cyclized compound $\mathbf{3 0}$ exhibited the greatest cytotoxic effects against neuroblastoma cells, with $\mathrm{IC}_{50}$ values of $13.3 \mu \mathrm{M}$ and $3.1 \mu \mathrm{M}$ towards SH-SY5Y and Kelly cells, respectively (Table 1) (Figure 7A,B). However, cyclization of the methyl ketone groups significantly decreased cytotoxic potency as the triyclic furoindole 34 and the tetracyclic furoindole 32 had $\mathrm{IC}_{50}$ values exceeding $20 \mu \mathrm{M}$ for both neuroblastoma cell lines. 
Table 1. Activity of compounds 30,32 and 34 against neurobalstoma cancer cell lines.

\begin{tabular}{ccc}
\hline Compound & $\begin{array}{c}\mathrm{IC}_{\mathbf{5 0}}(\mu \mathrm{M})^{\mathrm{a}} \\
\text { SH-SY5Y }^{\mathrm{a}}\end{array}$ & KELLY \\
\hline 30 & 13.3 & 3.1 \\
\hline 32 & $>20$ & $>20$ \\
\hline 34 & $>20$ & $>20$
\end{tabular}

a Compound concentration required to reduce cell viability by $50 \%$, as determined by the Alamar Blue assay, under conditions allowing untreated controls to undergo at least five consecutive rounds of multiplication.

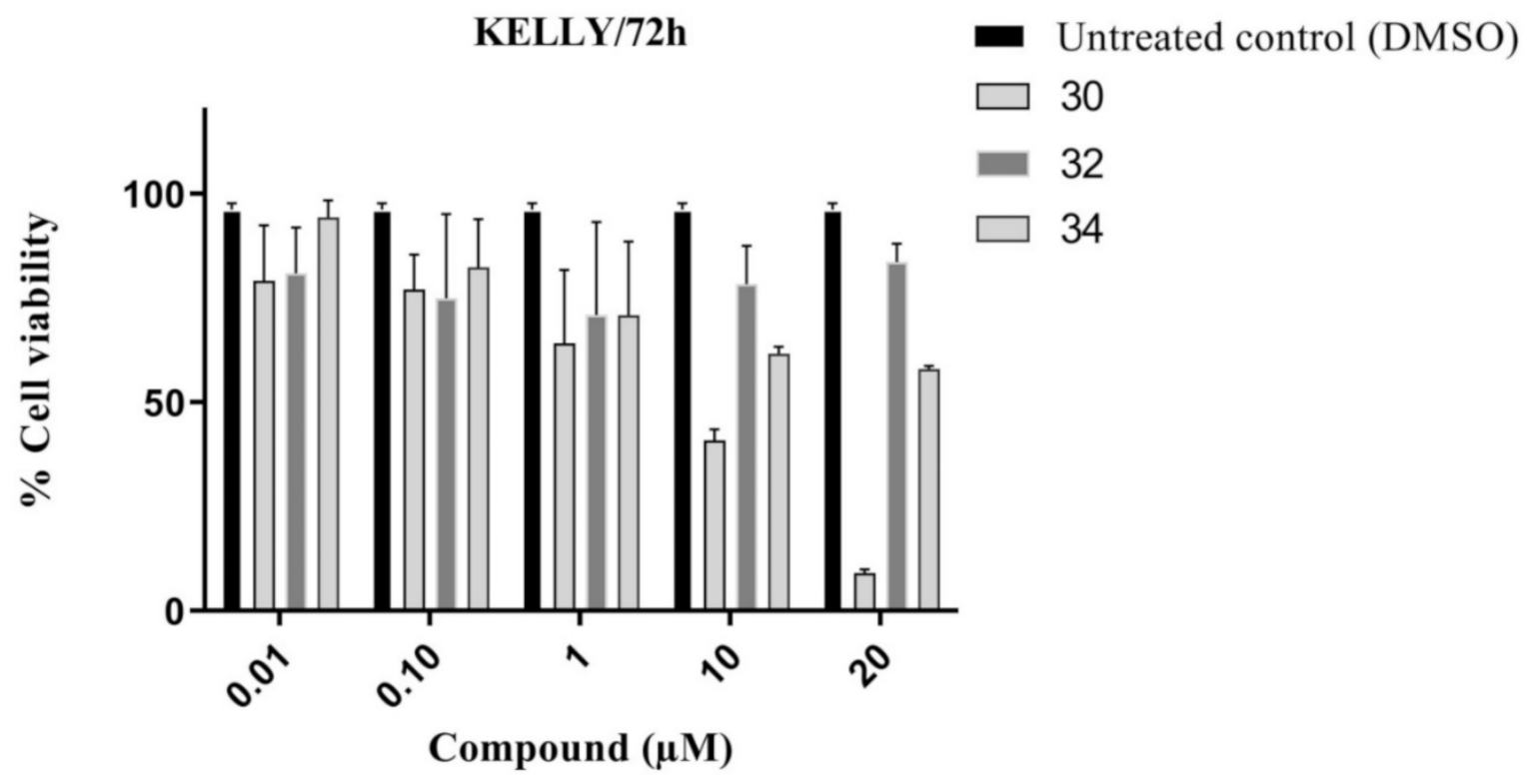

(A)

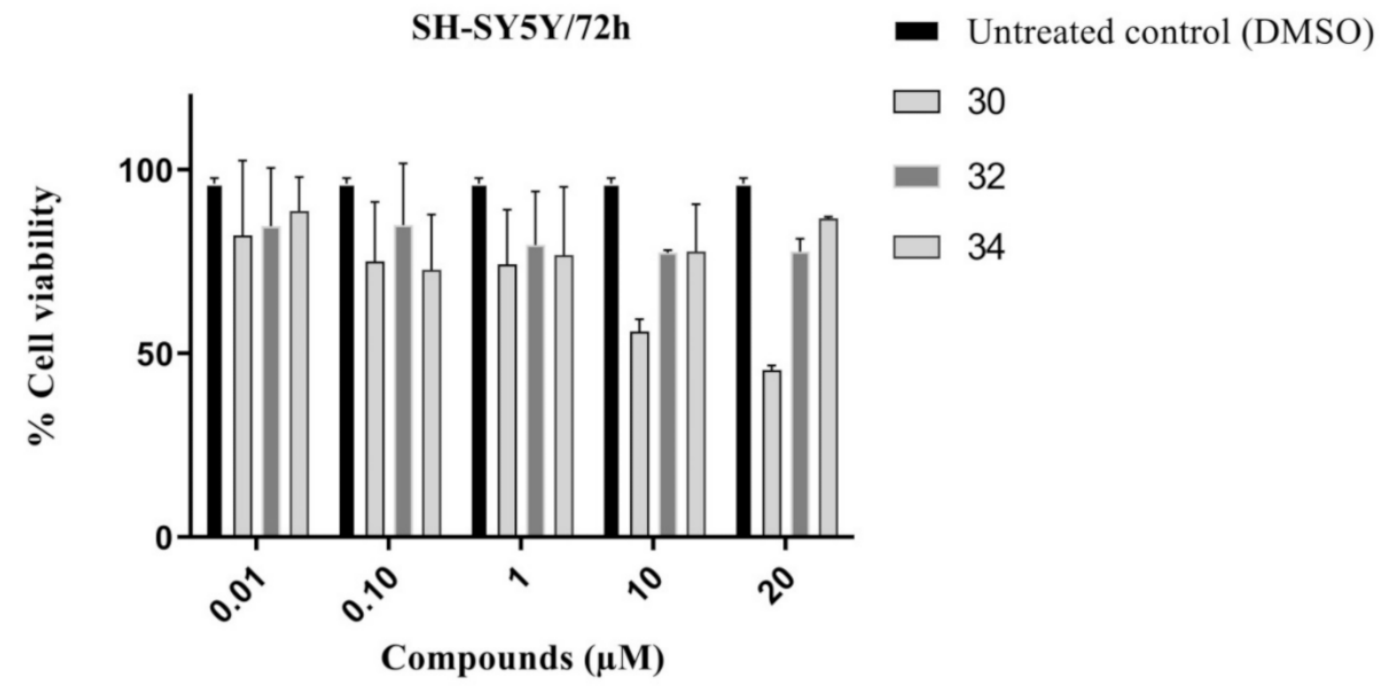

(B)

Figure 7. Cell viability of (A) KELLY (B) SH-SY5Y neuroblastoma cancer cells treated with compounds 30, 32 and 34 at different concentrations $(0.01,0.1,1,10,20 \mu \mathrm{M})$ over $72 \mathrm{~h}$. Error bars represent mean values ( \pm S.D.) for three independent determinations. 


\subsubsection{Toxicity Study against Normal Cells}

The most cytotoxic furoindoles, 31 and $\mathbf{3 2}$, and the best candidate compound, $\mathbf{4 3}$, for SAHA enhancement were screened against MRC-5 and WI-38 normal human lung fibroblast cells in order to investigate their level of selectivity for tumour cells. The toxicity of 31, 32 and 43 towards the non-malignant cells were found to be slightly lower than towards the cancer cells. While compound $\mathbf{3 1}$ was the most toxic furoindole against normal cells with an inhibition value of $23 \%$ against WI-38 cells at $10 \mu \mathrm{M}$, it still showed higher cytotoxicity against SH-SY5Y cells with $45 \%$ inhibition at the same concentration (Figure 8A). The tetracyclic furoindole 32 reduced MRC- 5 and WI- 38 cell viability by $5 \%$ and $16 \%$, respectively (Figure $8 \mathrm{~B}$ ). For compound 43 , it was toxic against the MRC-5 and WI-38 cell lines with $10 \%$ and $20 \%$ inhibitions; however, it was still more cytotoxic against Kelly cancer cells with at the same concentration of $10 \mu \mathrm{M}$ (Figure 8C). The $1 \mu \mathrm{M}$ SAHA treatment was also evaluated the normal human cells, and the SAHA was also found to be slightly toxic for MRC-5, but considerable inhibition was detected in the case of WI-38 cells.

\section{Compound 31}

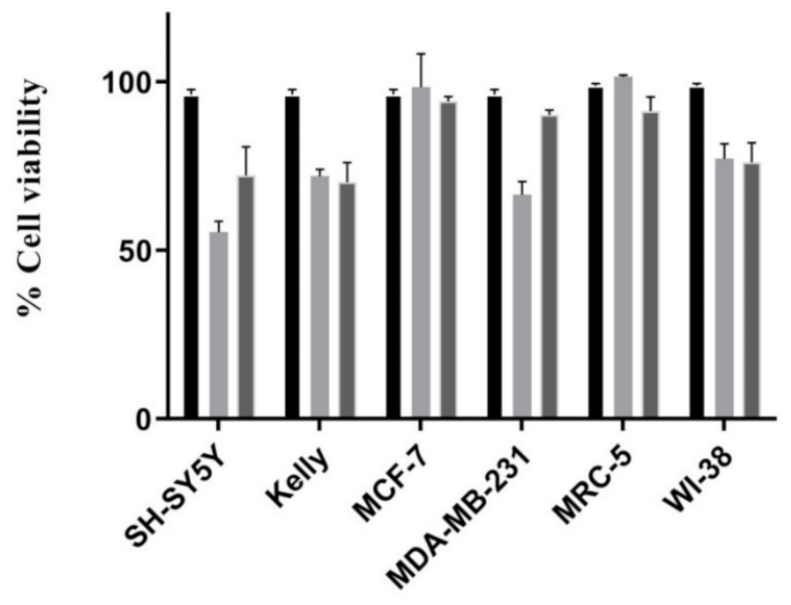

- Untreated control (DMSO)

- $31(10 \mu \mathrm{M})$

- $1 \mu \mathrm{M}$ SAHA

(A)

\section{Compound 32}

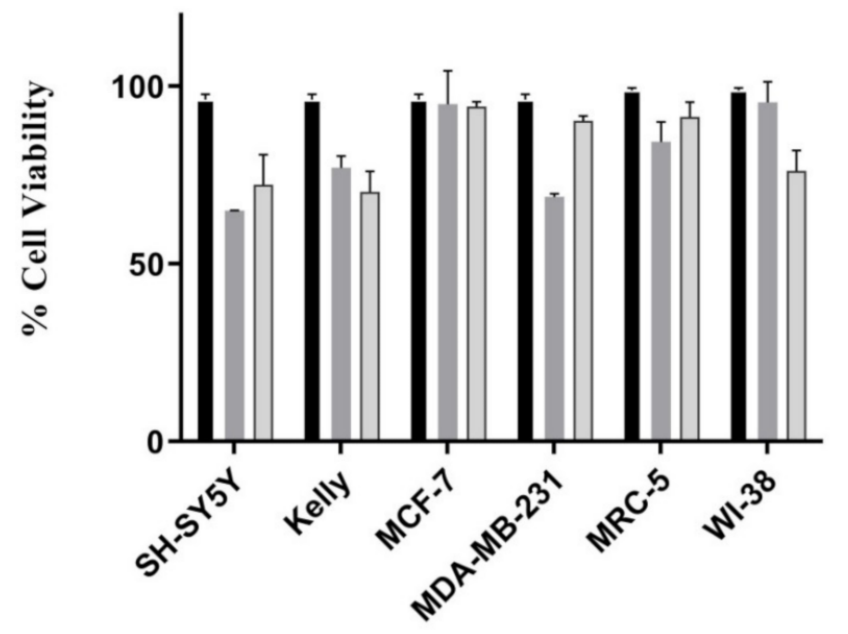

- Untreated control (DMSO)

$32(10 \mu \mathrm{M})$

$\square 1 \mu \mathrm{M}$ SAHA

(B)

Figure 8. Cont. 


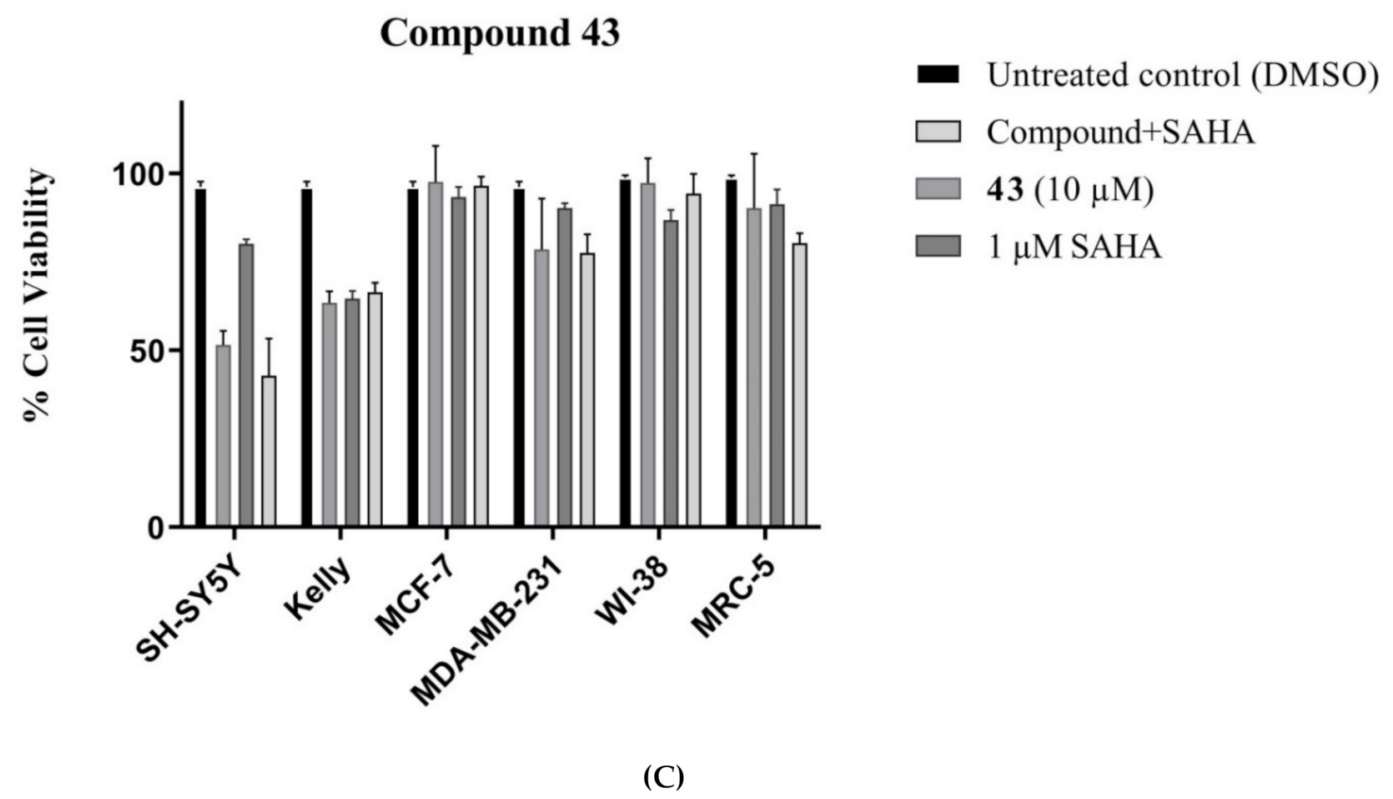

Figure 8. Comparative toxicity of compounds (A) 31, (B) 32 and (C) 43 (10 $\mu \mathrm{M}$ ) against cancer cells (SH-SY5Y, Kelly, MDA-MB-231 and MCF-7) and normal human fibroblasts (MRC-5 and WI-38) after $72 \mathrm{~h}$ exposure. Error bars represent mean values $( \pm$ S.D.) for three independent determinations.

Compounds 30 and 34 were also screened against WI-38 normal human cells to determine the effect of cyclization on the toxicity profile. Compound 34 showed a $15 \%$ reduction of WI-38 cell viability at a concentration of $10 \mu \mathrm{M}$ (Figure 9A), while compound 30 caused 47\% inhibition at the same concentration (Figure 9B). It was concluded that the cyclization process decreases the cytotoxic and toxic behaviours of the compounds against both the cancer and normal human cells.

Compound 34

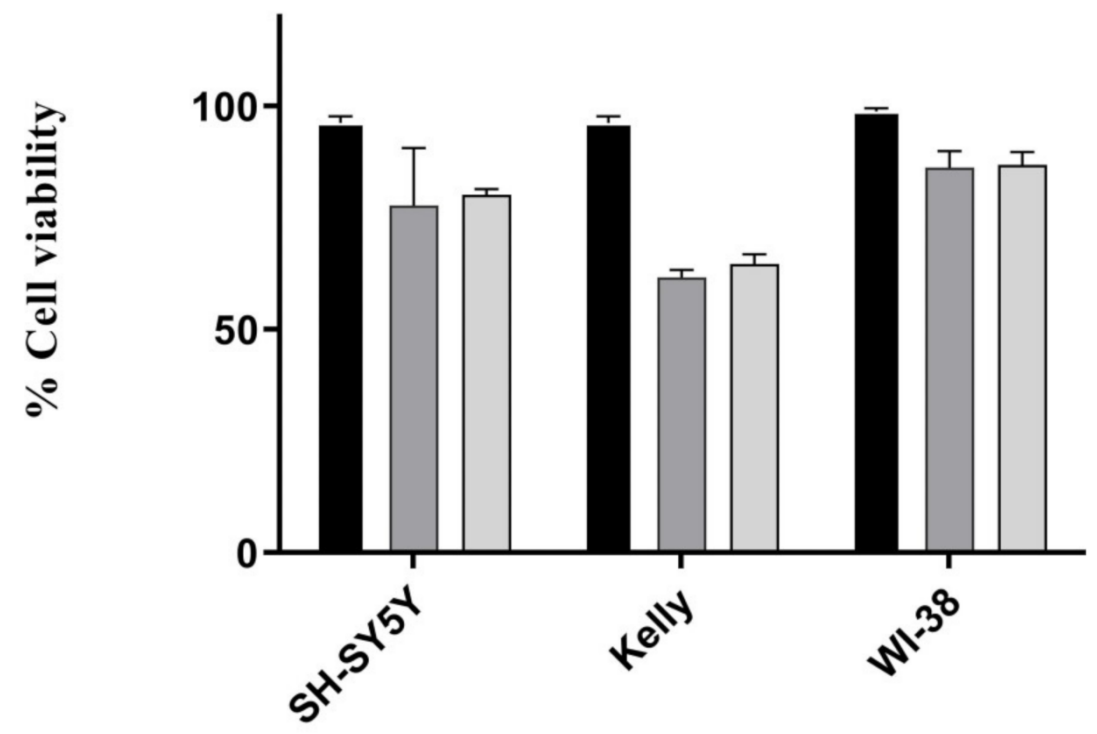

(A)

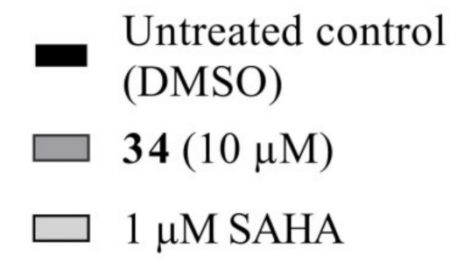

Figure 9. Cont. 


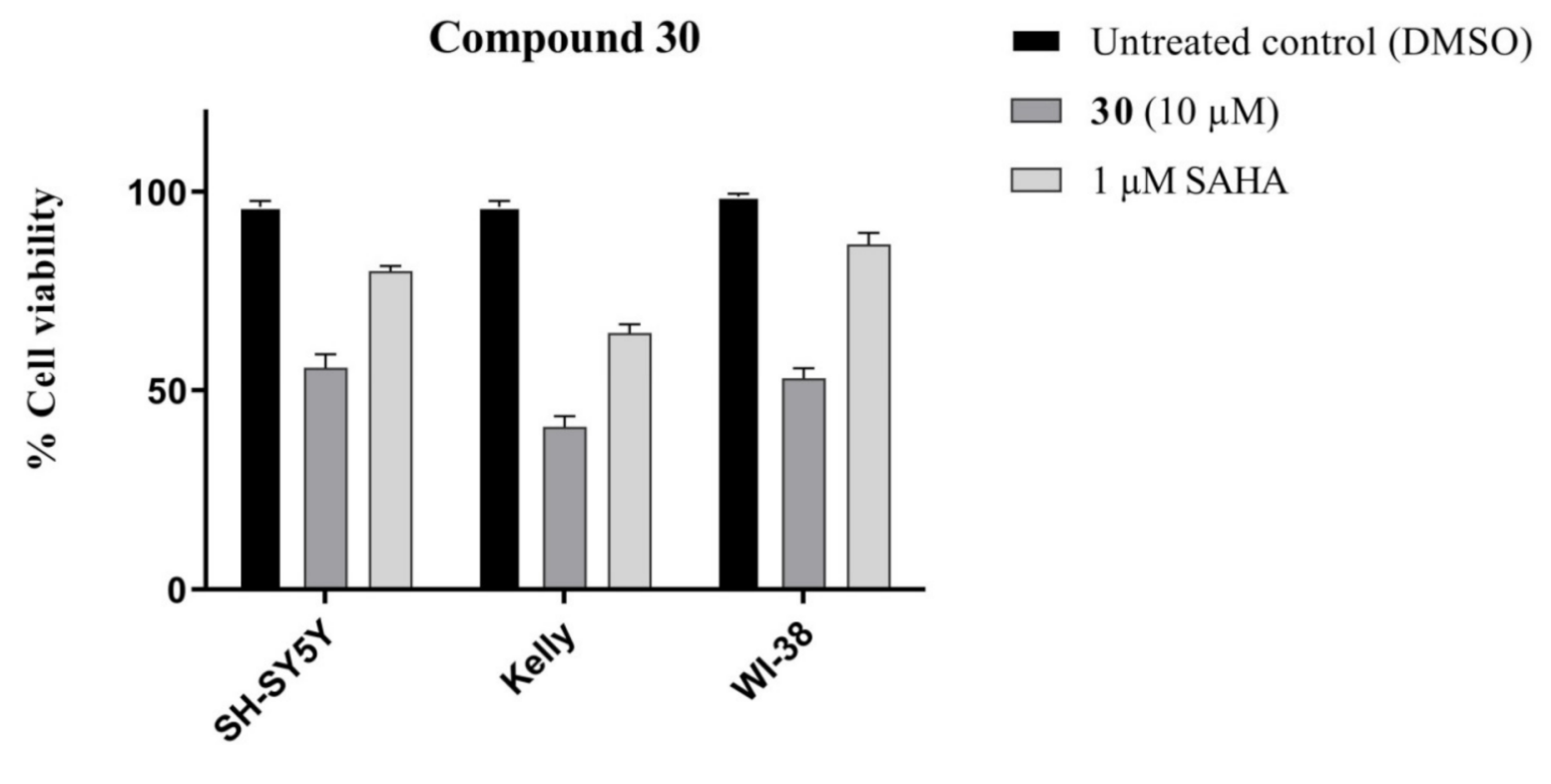

(B)

Figure 9. Comparative toxicity of (A) 34 and (B) 30 compounds $(10 \mu \mathrm{M})$ against SH-SY5Y, Kelly and WI-38 cell lines after $72 \mathrm{~h}$ exposure. Error bars represent mean values ( \pm S.D.) for three independent determinations.

\section{Materials and Methods}

\subsection{General Information}

Commercially available reagents were purchased from Fluka (Sydney, NSW, Australia), Aldrich (Sydney, NSW, Australia), Acros Organics (Morris Plains, NJ, USA), Alfa Aesar (Lancashire, UK) and Lancaster (Lancashire, UK) and purified if necessary. The synthetic procedures have been reported for all compounds as general methods and appropriate references have been given for known compounds. ${ }^{1} \mathrm{H}(300 \mathrm{MHz})$ and ${ }^{13} \mathrm{C}-\mathrm{NMR}$ $(75 \mathrm{MHz})$ spectra were obtained in the designated solvents on a DPX 300 spectrometer (Bruker, Sydney, NSW, Australia). Melting points were measured using a Mel-Temp melting point apparatus and are uncorrected. Infrared spectra were recorded on Avatar Series FT-IR spectrophotometer as KBr disks (Thermo Nicolet, Waltham, MA, USA). Ultraviolet spectra were measured using a Cary 100 spectrophotometer (Varian, Santa Clara, CA, USA) in the designated solvents and data reported as wavelength $(\lambda)$ in nm and adsorption coefficient $(\varepsilon)$ in $\mathrm{cm}^{-1} \mathrm{M}^{-1}$. High-resolution [ESI] mass spectra were recorded by the UNSW Bioanalytical Mass Spectrometry Facility, on an Orbitrap LTQ XL (Thermo Scientific, Waltham, MA, USA) ion trap mass spectrometer using a nanospray (nano-electrospray) ionization source.

Methyl 4,6-dihydroxyindole-2-carboxylate [22] (17): The title compound was prepared with the hydrogenolysis reaction from methyl 4,6-dibenzyloxyindole-2-carboxylate (13) (0.387 g, $1.0 \mathrm{mmol})$ and $5 \% \mathrm{Pd} / \mathrm{C}$ catalyst $(40 \mathrm{mg})$ in methanol/THF mixture $(15 \mathrm{~mL})$ to give the product (149 $\mathrm{mg}, 72 \%)$ as a yellow solid; m.p. $246-248{ }^{\circ} \mathrm{C}$ (lit. [22] not given); ${ }^{1} \mathrm{H}-\mathrm{NMR}$ (300 MHz, $d_{6}$-DMSO): $\delta 3.82\left(\mathrm{~s}, 3 \mathrm{H}, \mathrm{CO}_{2} \mathrm{Me}\right), 6.00$ (dd, $\left.J=2.3,0.9 \mathrm{~Hz}, 1 \mathrm{H}, \mathrm{H} 5\right), 6.26$ (dd, $J=2.3,0.9 \mathrm{~Hz}, 1 \mathrm{H}, \mathrm{H7}), 7.08(\mathrm{~d}, J=1.8 \mathrm{~Hz}, 1 \mathrm{H}, \mathrm{H} 3), 9.17$ and 9.66 (bs, each $1 \mathrm{H}, \mathrm{OH}), 11.31$ (bs, $1 \mathrm{H}, \mathrm{NH})$.

Methyl 5,6-dihydroxyindole-2-carboxylate (18): The title compound was prepared with the hydrogenolysis reaction from methyl 5,6-dibenzyloxyindole-2-carboxylate (14) (0.387 g, $1.0 \mathrm{mmol})$ and $5 \% \mathrm{Pd} / \mathrm{C}$ catalyst $(40 \mathrm{mg})$ in methanol/THF mixture $(15 \mathrm{~mL})$ to give the product $(159 \mathrm{mg}, 77 \%)$ as yellow solid; m.p. $256-258{ }^{\circ} \mathrm{C}$; IR (KBr): $v_{\max } 3437,3315,2953$, 2107, 1653, 1632, 1531, 1506, 1437, 1311, 1283, 1230, 1198, 1139, 992, 937, 849, 825, $767 \mathrm{~cm}^{-1}$; UV-vis $\left(\mathrm{CH}_{3} \mathrm{CN}\right): \lambda_{\max } 203 \mathrm{~nm}\left(\varepsilon\right.$ 42,100 $\left.\mathrm{cm}^{-1} \mathrm{M}^{-1}\right), 318(27,000) ;{ }^{1} \mathrm{H}-\mathrm{NMR}(300 \mathrm{MHz}$, 
$d_{6}$-DMSO): $\delta 3.82$ (s, 3H, $\left.\mathrm{CO}_{2} \mathrm{Me}\right), 6.79$ (d, $\left.J=0.8 \mathrm{~Hz}, 1 \mathrm{H}, \mathrm{H} 4\right), 6.88$ (s, 1H, H3), 6.90 $(\mathrm{d}, J=0.8 \mathrm{~Hz}, 1 \mathrm{H}, \mathrm{H} 7), 8.84$ and $9.17(\mathrm{bs}$, each $1 \mathrm{H}, \mathrm{OH}), 11.28(\mathrm{bs}, 1 \mathrm{H}, \mathrm{NH})$; ${ }^{13} \mathrm{C}-\mathrm{NMR}$ (75.6 MHz, $\left.\mathrm{CDCl}_{3}\right)$ : $52.0\left(\mathrm{CO}_{2} \mathrm{Me}\right), 97.3$ (C7), 105.4 (C4), 108.4 (C3), 120.3 (ArC), 125.0 (C2), 133.2 (ArC), 142.3 (C5), 146.7 (C6), $162.5\left(\mathrm{CO}_{2} \mathrm{Me}\right)$; HRMS (+ESI): Found $m / z 230.0423$ [M + $\mathrm{Na}]^{+}, \mathrm{C}_{10} \mathrm{H}_{9} \mathrm{NO}_{4} \mathrm{Na}$ requires 230.0424 .

Methyl 5-hydroxy-6-methoxy-1H-indole-2-carboxylate [23] (19): The title compound was prepared with the hydrogenolysis reaction from methyl 5-(benzyloxy)-6-methoxy- $1 H$-indole2-carboxylate (15) (0.311 g, $1.0 \mathrm{mmol})$ and 10\% Pd/C catalyst (32 $\mathrm{mg})$ in methanol/ THF mixture $(15 \mathrm{~mL})$ to give the product $(181 \mathrm{mg}, 82 \%)$ as yellow solid; m.p. $176-178{ }^{\circ} \mathrm{C}$ (lit. [23] 178-180 $\left.{ }^{\circ} \mathrm{C}\right) ;{ }^{1} \mathrm{H}-\mathrm{NMR}\left(300 \mathrm{MHz}, \mathrm{CDCl}_{3}\right): \delta 3.95$ (s, 3H, CO $\left.\mathrm{CO}_{2} \mathrm{Me}\right), 3.99$ (s, 3H, OMe), 5.57 (bs, 1H, OH), 6.86 (d, J = 0.9 Hz, 1H, H4), 7.11 (d, J = 2.1 Hz, 1H, H3), 7.16 (1H, s, H7), 8.77 (bs, $1 \mathrm{H}, \mathrm{NH})$.

Methyl 6-hydroxy-5-methoxy-1H-indole-2-carboxylate [24] (20): The title compound was prepared with the hydrogenolysis reaction from methyl 6-(benzyloxy)-5-methoxy- $1 H$-indole2-carboxylate (16) $(0.311 \mathrm{~g}, 1.0 \mathrm{mmol})$ and $10 \% \mathrm{Pd} / \mathrm{C}$ catalyst (32 $\mathrm{mg})$ in methanol/ THF mixture $(15 \mathrm{~mL})$ to give the product $(196 \mathrm{mg}, 89 \%)$ as yellow solid; m.p. $184-186{ }^{\circ} \mathrm{C}$ (lit. [24] not given); ${ }^{1} \mathrm{H}-\mathrm{NMR}\left(300 \mathrm{MHz}, \mathrm{CDCl}_{3}\right): \delta 3.95\left(\mathrm{~s}, 3 \mathrm{H}, \mathrm{CO}_{2} \mathrm{Me}\right), 3.98(\mathrm{~s}, 3 \mathrm{H}, \mathrm{OMe})$, 5.99 (bs, 1H, OH), 6.96 (d, J = 0.9 Hz, 1H, H7), 7.06 (s, 1H, H4), 7.14 (d, J = 2.1 Hz, 1H, H3), 8.86 (bs, $1 \mathrm{H}, \mathrm{NH}$ ).

\subsubsection{GP-1: General Procedure for the Synthesis of Indole Ethers}

A mixture of methyl hydroxyindole-2-carboxylate (1 equiv.) and $\alpha$-haloketone (per hydroxyl group, 1 equiv.) in acetone $(100 \mathrm{~mL})$ was treated with potassium carbonate (per hydroxyl group, 1 equiv.) and heated at reflux overnight. Acetone was removed under reduced pressure, and water $(100 \mathrm{~mL})$ was added to the residue. The product was extracted with ethyl acetate $(3 \times 100 \mathrm{~mL})$, and the combined organic phases were dried over anhydrous sodium sulphate and concentrated under vacuum. The crude product was purified using gravity column chromatography, eluted with ethylacetate/n-hexane (1:10), to give the indole ethers.

\subsubsection{GP-2: General Procedure for the Synthesis of Furoindoles}

A solution of indole ether $(0.26 \mathrm{mmol})$ in DCM $(10 \mathrm{~mL})$ was treated with trifluoroacetic acid (10 drops) and heated at reflux for $24 \mathrm{~h}$. The reaction mixture was poured into crushed ice $(100 \mathrm{~g})$, and the precipitate collected via filtration and washed with water. The crude product was purified using gravity column chromatography, eluted with DCM/n-hexane $(2: 10)$, to give the furoindole.

Methyl 6-methoxy-5-(2-oxopropoxy)-1H-indole-2-carboxylate (21): The title compound was prepared as described in GP-1 from methyl 5-hydroxy-6-methoxyindole-2-carboxylate (19) (107.2 $\mathrm{mg}, 0.485 \mathrm{mmol})$, chloroacetone $(44.2 \mathrm{mg}, 0.485 \mathrm{mmol})$ and potassium carbonate $(66.9 \mathrm{mg}, 0.485 \mathrm{mmol})$ to give the product $(108.8 \mathrm{mg}, 81 \%)$ as a white solid; m.p. $164-166{ }^{\circ} \mathrm{C}$; IR (KBr): $v_{\max } 3314,2879,2828,2318,2117,1925,1688,1632,1521,1445,1356,1250,1151$, 1065, 1019, 998, 893, 759, $671 \mathrm{~cm}^{-1}$; UV-vis $\left(\mathrm{CH}_{3} \mathrm{CN}\right): \lambda_{\max } 208 \mathrm{~nm}\left(\varepsilon 30,600 \mathrm{~cm}^{-1} \mathrm{M}^{-1}\right)$, $318(22,100) ;{ }^{1} \mathrm{H}-\mathrm{NMR}\left(300 \mathrm{MHz}, \mathrm{CDCl}_{3}\right): \delta 2.34$ (s, 3H, COMe), 3.95 (s, 3H, CO $\left.2 \mathrm{Me}\right), 3.97$ (s, $3 \mathrm{H}, \mathrm{OMe}), 4.64\left(\mathrm{~s}, 2 \mathrm{H}, \mathrm{CH}_{2}\right), 6.91(\mathrm{~d}, J=0.9 \mathrm{~Hz}, 1 \mathrm{H}, \mathrm{H} 7), 7.02(\mathrm{~s}, 1 \mathrm{H}, \mathrm{H} 3), 7.11$ (d, J = 0.9 Hz, 1H, H4), 8.90 (bs, $1 \mathrm{H}, \mathrm{NH}) ;{ }^{13} \mathrm{C}-\mathrm{NMR}\left(75.6 \mathrm{MHz}, \mathrm{CDCl}_{3}\right)$ : $\delta 26.5(\mathrm{COMe}), 51.9\left(\mathrm{CO}_{2} \mathrm{Me}\right)$, 56.1 (Ome), $75.0\left(\mathrm{CH}_{2}\right), 94.4$ (C7), 106.0 (C4), 108.9 (C3), 120.3 (aryl C), 126.9 (C2), 132.9 (aryl C), 144.5 (C5), 150.4 (C6), $162.2\left(\mathrm{CO}_{2} \mathrm{Me}\right), 206.5$ (COMe); HRMS (+ESI): Found $m / z$ $300.0832,[\mathrm{M}+\mathrm{Na}]^{+}, \mathrm{C}_{14} \mathrm{H}_{15} \mathrm{NO}_{5} \mathrm{Na}$ requires 300.0842 .

Methyl 5-methoxy-6-(2-oxopropoxy)-1H-indole-2-carboxylate (23): The title compound was prepared as described in GP-1 from methyl 5-methoxy-6-hydroxyindole-2-carboxylate (20) (107.2 $\mathrm{mg}, 0.485 \mathrm{mmol})$, chloroacetone $(44.2 \mathrm{mg}, 0.485 \mathrm{mmol})$ and potassium carbonate $(66.9 \mathrm{mg}, 0.485 \mathrm{mmol})$ to give the product $(104.8 \mathrm{mg}, 78 \%)$ as a white solid; m.p. $170-172{ }^{\circ} \mathrm{C}$; 
IR (KBr): $v_{\max } 3316,2918,2845,2339,2109,1910,1680,1642,1520,1428,1356,1285,1209$, $1160,1017,890,817,761,666 \mathrm{~cm}^{-1}$; UV-vis $\left(\mathrm{CH}_{3} \mathrm{CN}\right): \lambda_{\max } 209 \mathrm{~nm}\left(\varepsilon 30,700 \mathrm{~cm}^{-1} \mathrm{M}^{-1}\right)$, 309 (18,500); ${ }^{1} \mathrm{H}-\mathrm{NMR}\left(300 \mathrm{MHz}, \mathrm{CDCl}_{3}\right): \delta 2.33$ (s, 3H, COMe), 3.94 (s, 3H, CO $\left.2 \mathrm{Me}\right), 3.95$ (s, $3 \mathrm{H}, \mathrm{OMe}), 4.65\left(\mathrm{~s}, 2 \mathrm{H}, \mathrm{CH}_{2}\right), 6.80(\mathrm{~d}, J=0.7 \mathrm{~Hz}, 1 \mathrm{H}, \mathrm{H} 4), 7.12(\mathrm{~s}, 1 \mathrm{H}, \mathrm{H} 3), 7.13$ (d, J = 0.7 Hz, 1H, H7), 9.05 (bs, $1 \mathrm{H}, \mathrm{NH}) ;{ }^{13} \mathrm{C}-\mathrm{NMR}\left(75.6 \mathrm{MHz}, \mathrm{CDCl}_{3}\right): \delta 26.5(\mathrm{COMe}), 51.8\left(\mathrm{CO}_{2} \mathrm{Me}\right)$, 56.2 (OMe), $74.5\left(\mathrm{CH}_{2}\right), 95.5(\mathrm{C} 7), 103.4(\mathrm{C} 4), 108.6(\mathrm{C} 3), 121.6$ (aryl C), $126.3(\mathrm{C} 2), 131.6$ (aryl C), 146.4 (C6), 148.1 (C5), 162.2 ( $\left.\mathrm{CO}_{2} \mathrm{Me}\right), 206.3$ (COMe); HRMS (+ESI): Found $\mathrm{m} / \mathrm{z}$ $300.0842,[\mathrm{M}+\mathrm{Na}]^{+}, \mathrm{C}_{14} \mathrm{H}_{15} \mathrm{NO}_{5} \mathrm{Na}$ requires 300.0842 .

Methyl 6-methoxy-5-((3-oxobutan-2-yl)oxy)-1H-indole-2-carboxylate (22): The title compound was prepared as described in GP-1 from methyl 5-hydroxy-6-methoxyindole-2-carboxylate (19) $(107.2 \mathrm{mg}, 0.485 \mathrm{mmol}), 3$-chloro-2-butanone $(51.4 \mathrm{mg}, 0.485 \mathrm{mmol})$, potassium carbonate $(66.9 \mathrm{mg}, 0.485 \mathrm{mmol})$ to give the product $(120 \mathrm{mg}, 85 \%)$ as a white solid; m.p. 134-136 ${ }^{\circ} \mathrm{C}$; IR (KBr): $v_{\max } 3308,2928,2802,2287,2116,1965,1676,1622,1519,1440,1358$, 1274, 1191, 1142, 1092, 1013, 937, 820, 766, $688 \mathrm{~cm}^{-1}$; UV-vis $\left(\mathrm{CH}_{3} \mathrm{CN}\right): \lambda_{\max } 207 \mathrm{~nm}(\varepsilon$ 31,400 cm $\left.{ }^{-1} \mathrm{M}^{-1}\right), 319(21,700) ;{ }^{1} \mathrm{H}-\mathrm{NMR}\left(300 \mathrm{MHz}, \mathrm{CDCl}_{3}\right): \delta 1.56(\mathrm{~d}, J=6.9 \mathrm{~Hz}, 3 \mathrm{H}$, CHMe), 2.29 (s, 3H, COMe), 3.94 (s, 3H, CO $2 \mathrm{Me}), 3.95$ (s, 3H, OMe), 4.57 (q, J = 6.9 Hz, 1H, CHMe), 6.90 (d, J = 0.8 Hz, 1H, H7), 7.04 (s, 1H, H3), 7.10 (d, J = 0.9 Hz, 1H, H4), 8.92 (bs, $1 \mathrm{H}, \mathrm{NH}) ;{ }^{13} \mathrm{C}-\mathrm{NMR}\left(75.6 \mathrm{MHz}, \mathrm{CDCl}_{3}\right): \delta 17.6(\mathrm{CHMe}), 24.7(\mathrm{COMe}), 51.8\left(\mathrm{CO}_{2} \mathrm{Me}\right), 56.0$ (Ome), 81.4 (CHMe), 94.4 (C7), 107.8 (C4), 108.9 (C3), 120.3 (aryl C), 126.1 (C2), 133.0 (aryl C), 143.9 (C6), 150.8 (C5), 162.2 (CO $2 \mathrm{Me}), 211.0$ (COMe); HRMS (+ESI): Found m/z 314.0988, $[\mathrm{M}+\mathrm{Na}]^{+}, \mathrm{C}_{15} \mathrm{H}_{17} \mathrm{NO}_{5} \mathrm{Na}$ requires 314.0999.

Methyl 5-methoxy-6-((3-oxobutan-2-yl)oxy)-1H-indole-2-carboxylate (24): The title compound was prepared as described in GP-1 from methyl 5-methoxy-6-hydroxyindole-2-carboxylate (20) $(107.2 \mathrm{mg}, 0.485 \mathrm{mmol}), 3$-chloro-2-butanone $(51.4 \mathrm{mg}, 0.485 \mathrm{mmol})$, potassium carbonate $(66.9 \mathrm{mg}, 0.485 \mathrm{mmol})$ to give the product $(114 \mathrm{mg}, 81 \%)$ as a white solid; m.p. 136-138 ${ }^{\circ} \mathrm{C}$; IR (KBr): $v_{\max } 3321,2915,2842,2327,2108,1928,1678,1640,1520,1438,1354$, $1288,1221,1101,1022,937,848,830,766,672 \mathrm{~cm}^{-1}$; UV-vis $\left(\mathrm{CH}_{3} \mathrm{CN}\right): \lambda_{\max } 210 \mathrm{~nm}(\varepsilon$ 34,200 cm $\left.{ }^{-1} \mathrm{M}^{-1}\right), 289$ (20,300); ${ }^{1} \mathrm{H}-\mathrm{NMR}\left(300 \mathrm{MHz}, \mathrm{CDCl}_{3}\right): \delta 1.58(\mathrm{~d}, J=6.9 \mathrm{~Hz}, 3 \mathrm{H}$, CHMe), 2.26 (s, 3H, COMe), 3.92 (s, 3H, CO $2 \mathrm{Me}$ ), 3.95 (s, 3H, OMe) 4.63 (q, J = 6.9 Hz, 1H, CHMe), 6.80 (d, J = 0.9 Hz, 1H, H4), 7.12 (s, 1H, H3), 7.14 (d, J = 0.9 Hz, 1H, H7), 8.87 (bs, $1 \mathrm{H}, \mathrm{NH}) ;{ }^{13} \mathrm{C}-\mathrm{NMR}\left(75.6 \mathrm{MHz} \mathrm{CDCl}_{3}\right): \delta 17.6$ (CHMe), $24.5(\mathrm{COMe}), 51.8\left(\mathrm{CO}_{2} \mathrm{Me}\right), 56.2$ (OMe), 81.0 (CHMe), 97.8 (C7), 103.6 (C4), 108.6 (C3), 121.7 (aryl C), 126.4 (C2), 131.6 (aryl C), 146.7 (C6), 147.8 (C5), 162.1 (CO $\left.\mathrm{CO}_{2} \mathrm{Me}\right), 210.8$ (COMe); HRMS (+ESI): Found m/z 314.0991, $[\mathrm{M}+\mathrm{Na}]^{+}, \mathrm{C}_{15} \mathrm{H}_{17} \mathrm{NO}_{5} \mathrm{Na}$ requires 314.0999.

Methyl 4-methoxy-1-methyl-6H-furo[3,2-e]indole-7-carboxylate (25): The title compound was prepared as described in GP-2 from methyl 6-methoxy-5-(2-oxopropoxy)-1H-indole-2carboxylate $(\mathbf{2 1})(72.0 \mathrm{mg}, 0.26 \mathrm{mmol})$ with trifluoroacetic acid (10 drops) in dichloromethane $(10 \mathrm{~mL})$ to give the product $(49.1 \mathrm{mg}, 73 \%)$ as a white solid; m.p. $202-204{ }^{\circ} \mathrm{C}$; IR (KBr): $\nu_{\max } 3289,2919,2857,2342,2113,1933,1673,1621,1521,1439,1391,1280,1186,1144,1083$, 1030, 997, 916, 761, $693 \mathrm{~cm}^{-1}$; UV-vis $\left(\mathrm{CH}_{3} \mathrm{CN}\right): \lambda_{\max } 209 \mathrm{~nm}\left(\varepsilon 33,800 \mathrm{~cm}^{-1} \mathrm{M}^{-1}\right), 312$ (37.900), 324 (37,500); ${ }^{1} \mathrm{H}-\mathrm{NMR}\left(300 \mathrm{MHz}, \mathrm{CDCl}_{3}\right): \delta 2.48(\mathrm{~d}, J=1.1 \mathrm{~Hz}, 3 \mathrm{H}, \mathrm{Me}), 3.97(\mathrm{~s}, 3 \mathrm{H}$, $\left.\mathrm{CO}_{2} \mathrm{Me}\right), 4.05$ (s, 3H, OMe), 6.77 (s, 1H, H5), 7.46 (d, J = 1.4 Hz, 1H, H8), 7.51 (d, J = 1.1 Hz, 1H, H2), 9.03 (bs, 1H, NH); ${ }^{13} \mathrm{C}-\mathrm{NMR}\left(75.6 \mathrm{MHz}, \mathrm{CDCl}_{3}\right): \delta 9.3(\mathrm{C}-\mathrm{Me}), 51.8\left(\mathrm{CO}_{2} \mathrm{Me}\right), 56.1$ (Ome), 107.1 (C8), 114.4 (aryl C), 116.9 (C5), 122.5 (C1), 125.1 (aryl C), 134.3 (C7), 140.8 (aryl C), 141.4 (aryl C), 142.9 (C2), 146.1 (C4), 162.3 (CO 2 Me); HRMS (+ESI): Found m/z 282.0731, $[\mathrm{M}+\mathrm{Na}]^{+}, \mathrm{C}_{14} \mathrm{H}_{13} \mathrm{NO}_{4} \mathrm{Na}$ requires 282.0737 .

Methyl 5-methoxy-8-methyl-1H-furo[2,3-g]indole-2-carboxylate (27): The title compound was prepared as described in GP-2 from methyl 5-methoxy-6-(2-oxopropoxy)-1H-indole-2carboxylate (23) $(72.0 \mathrm{mg}, 0.26 \mathrm{mmol})$ with trifluoroacetic acid (10 drops) in dichloromethane $(10 \mathrm{~mL})$ to give the product $(41.1 \mathrm{mg}, 61 \%)$ as a white solid; m.p. $182-184{ }^{\circ} \mathrm{C}$; IR $(\mathrm{KBr})$ : $\nu_{\max } 3294,2919,2849,2370,2119,1917,1683,1625,1532,1433,1380,1290,1196,1146,1041$, 989, 920, 823, 746, $674 \mathrm{~cm}^{-1}$; UV-vis $\left(\mathrm{CH}_{3} \mathrm{CN}\right): \lambda_{\max } 213 \mathrm{~nm}\left(\varepsilon 20,200 \mathrm{~cm}^{-1} \mathrm{M}^{-1}\right), 250$ (21,900), $294(16,500) ;{ }^{1} \mathrm{H}-\mathrm{NMR}\left(300 \mathrm{MHz}, \mathrm{CDCl}_{3}\right): \delta 2.53(\mathrm{~d}, J=1.3 \mathrm{~Hz}, 3 \mathrm{H}, \mathrm{Me}), 3.98(\mathrm{~s}, 3 \mathrm{H}$, 
$\left.\mathrm{CO}_{2} \mathrm{Me}\right), 4.05$ (s, 3H, OMe), $6.97(\mathrm{~s}, 1 \mathrm{H}, \mathrm{H} 4), 7.28(\mathrm{~d}, J=3.0 \mathrm{~Hz}, 1 \mathrm{H}, \mathrm{H} 3), 7.49(\mathrm{~d}, J=1.3 \mathrm{~Hz}$, 1H, H7), 9.12 (bs, $1 \mathrm{H}, \mathrm{NH}),{ }^{13} \mathrm{C}-\mathrm{NMR}\left(75.6 \mathrm{MHz}, \mathrm{CDCl}_{3}\right): \delta 9.7(\mathrm{C}-\mathrm{Me}), 51.8\left(\mathrm{CO}_{2} \mathrm{Me}\right), 56.1$ (OMe), 109.7 (C3), 114.8 (C4), 115.1 (C8), 122.8 (C2), 125.4 (aryl C), 125.7 (aryl C), 140.8 (2×aryl C), 142.9 (C7), 145.5 (C5), $162.3\left(\mathrm{CO}_{2} \mathrm{Me}\right)$; HRMS (+ESI): Found $m / z$ 282.0730, [M + $\mathrm{Na}]^{+}, \mathrm{C}_{14} \mathrm{H}_{13} \mathrm{NO}_{4} \mathrm{Na}$ requires 282.0737 .

Methyl 4-methoxy-1,2-dimethyl-6H-furo[3,2-e]indole-7-carboxylate (26): The title compound was prepared as described in GP-2 from methyl 6-methoxy-5-((3-oxobutan-2-yl)oxy)-1Hindole-2-carboxylate $(22)(75.7 \mathrm{mg}, 0.26 \mathrm{mmol})$ with the catalytic amount of trifluoroacetic acid (10 drops) in dichloromethane $(10 \mathrm{~mL})$ to give the product $(56.1 \mathrm{mg}, 79 \%)$ as a white solid; m.p. 182- $184^{\circ} \mathrm{C}$; IR (KBr): $v_{\max } 3308,2939,2855,2342,2116,1933,1671,1625,1520$, $1438,1371,1280,1211,1133,1035,1012,927,807,684 \mathrm{~cm}^{-1}$; UV-vis $\left(\mathrm{CH}_{3} \mathrm{CN}\right): \lambda_{\max } 211 \mathrm{~nm}$ ( $\left.131,400 \mathrm{~cm}^{-1} \mathrm{M}^{-1}\right), 314(38,400) ;{ }^{1} \mathrm{H}-\mathrm{NMR}\left(300 \mathrm{MHz}, \mathrm{CDCl}_{3}\right): \delta 2.41(\mathrm{~d}, J=0.8 \mathrm{~Hz}, 3 \mathrm{H}$, $\mathrm{Me}), 2.48(\mathrm{~d}, J=0.8 \mathrm{~Hz}, 3 \mathrm{H}, \mathrm{Me}), 3.98\left(\mathrm{~s}, 3 \mathrm{H}, \mathrm{CO}_{2} \mathrm{Me}\right), 4.06(\mathrm{~s}, 3 \mathrm{H}, \mathrm{OMe}), 6.72(\mathrm{~s}, 1 \mathrm{H}, \mathrm{H} 5)$, $7.46(\mathrm{~d}, J=0.9 \mathrm{~Hz}, 1 \mathrm{H}, \mathrm{H} 8), 8.96$ (bs, $1 \mathrm{H}, \mathrm{NH}) ;{ }^{13} \mathrm{C}-\mathrm{NMR}\left(75.6 \mathrm{MHz}, \mathrm{CDCl}_{3}\right): \delta 9.4(\mathrm{Me})$, $11.8(\mathrm{Me}), 51.7\left(\mathrm{CO}_{2} \mathrm{Me}\right), 56.0(\mathrm{Ome}), 107.1$ (Cland aryl C), 111.2 (C8), 114.2 (C5), 123.7 (aryl C), 124.9 (C7), $134.4(\operatorname{aryl} C), 139.6(\mathrm{C} 4), 145.7(\operatorname{aryl} \mathrm{C}), 150.6(\mathrm{C} 2), 162.3\left(\mathrm{CO}_{2} \mathrm{Me}\right)$; HRMS (+ESI): Found $m / z$ 296.0889, $[\mathrm{M}+\mathrm{Na}]^{+}, \mathrm{C}_{15} \mathrm{H}_{15} \mathrm{NO}_{4} \mathrm{Na}$ requires 296.0893 .

Methyl 5-methoxy-7,8-dimethyl-1H-furo[2,3-g]indole-2-carboxylate (28): The title compound was prepared as described in GP-2 from methyl 5-methoxy-6-((3-oxobutan-2-yl)oxy)-1Hindole-2-carboxylate $(24)(75.7 \mathrm{mg}, 0.26 \mathrm{mmol})$ with the catalytic amount of trifluoroacetic acid (10 drops) in dichloromethane $(10 \mathrm{~mL})$ to give the product $(47.6 \mathrm{mg}, 67 \%)$ as a white solid; m.p. 176-178 ${ }^{\circ} \mathrm{C}$; IR (KBr): $v_{\max } 3297,2917,2845,2342,2092,1942,1684,1593,1529$, $1431,1364,1293,1236,1192,1048,995,928,829,766,670 \mathrm{~cm}^{-1}$; UV-vis $\left(\mathrm{CH}_{3} \mathrm{CN}\right): \lambda_{\max }$ $215 \mathrm{~nm}\left(\varepsilon 29,500 \mathrm{~cm}^{-1} \mathrm{M}^{-1}\right), 251$ (33,800), 299 (22.300); ${ }^{1} \mathrm{H}-\mathrm{NMR}\left(300 \mathrm{MHz}, \mathrm{CDCl}_{3}\right): \delta 2.45$ $(\mathrm{d}, J=0.8 \mathrm{~Hz}, 3 \mathrm{H}, \mathrm{Me}), 2.47(\mathrm{~d}, J=0.8 \mathrm{~Hz}, 3 \mathrm{H}, \mathrm{Me}), 3.97\left(\mathrm{~s}, 3 \mathrm{H}, \mathrm{CO}_{2} \mathrm{Me}\right), 4.05(\mathrm{~s}, 3 \mathrm{H}, \mathrm{OMe})$, 6.90 (s, 1H, H4), 7.26 (d, J = 2.2 Hz, 1H, H3), 9.06 (bs, $1 \mathrm{H}, \mathrm{NH}) ;{ }^{13} \mathrm{C}-\mathrm{NMR}\left(75.6 \mathrm{MHz}, \mathrm{CDCl}_{3}\right)$ : 反 $9.4(\mathrm{Me}), 11.8(\mathrm{Me}), 51.7\left(\mathrm{CO}_{2} \mathrm{Me}\right), 56.0(\mathrm{OMe}), 107.1(\mathrm{C} 3), 111.2(\mathrm{C} 4), 114.2(\mathrm{C} 8), 123.7$ (aryl C), $124.9(\operatorname{aryl} C), 127.0(\mathrm{C} 2), 129.1(\operatorname{aryl} \mathrm{C}), 134.4(\operatorname{aryl} \mathrm{C}), 145.7$ (C5), 150.6 (C7), 162.3 $\left(\mathrm{CO}_{2} \mathrm{Me}\right)$; HRMS (+ESI): Found $m / z$ 274.1071, $[\mathrm{M}+\mathrm{H}]^{+}, \mathrm{C}_{15} \mathrm{H}_{16} \mathrm{NO}_{4}$ requires 274.1074.

Methyl 4,6-bis(2-oxopropoxy)-1H-indole-2-carboxylate (29): The title compound was prepared as described in GP-1 from methyl 4,6-dihdroxyindole-2-carboxylate (17) $(100.4 \mathrm{mg}, 0.485 \mathrm{mmol})$, chloroacetone $(88.4 \mathrm{mg}, 0.97 \mathrm{mmol})$, potassium carbonate $(123.8 \mathrm{mg}, 0.97 \mathrm{mmol})$ to give the product $(126.9 \mathrm{mg}, 82 \%)$ as a white solid; m.p. $184-186^{\circ} \mathrm{C}$; IR (KBr): $v_{\max } 3305,2919$, 2822, 2341, 2107, 1898, 1688, 1626, 1584, 1520, 1435, 1354, 1275, 1200, 1144, 985, 951, 803, $767 \mathrm{~cm}^{-1}$; UV-vis $\left(\mathrm{CH}_{3} \mathrm{CN}\right): \lambda_{\max } 203 \mathrm{~nm}\left(\varepsilon 30,400 \mathrm{~cm}^{-1} \mathrm{M}^{-1}\right), 245(23,000), 305(23,200)$; ${ }^{1} \mathrm{H}-\mathrm{NMR}\left(300 \mathrm{MHz}, \mathrm{CDCl}_{3}\right): \delta 2.33$ (s, 3H, Me), 2.39 (s, 3H, Me), $3.95\left(\mathrm{~s}, 3 \mathrm{H}, \mathrm{CO}_{2} \mathrm{Me}\right), 4.59$ $\left(\mathrm{d}, J=0.8 \mathrm{~Hz}, 2 \mathrm{H}, \mathrm{CH}_{2}\right), 4.67\left(\mathrm{~d}, J=0.8 \mathrm{~Hz}, 2 \mathrm{H}, \mathrm{CH}_{2}\right), 6.28(\mathrm{~d}, J=1.7 \mathrm{~Hz}, 1 \mathrm{H}, \mathrm{H} 5), 6.37(\mathrm{~d}$, $J=1.7 \mathrm{~Hz}, 1 \mathrm{H}, \mathrm{H7}), 7.26$ (d, J = 2.2 Hz, 1H, H3), 8.96 (bs, 1H, NH); ${ }^{13} \mathrm{C}-\mathrm{NMR}(75.6 \mathrm{MHz}$, $\left.\mathrm{CDCl}_{3}\right): \delta 30.9(2 \times \mathrm{COMe}), 51.9\left(\mathrm{CO}_{2} \mathrm{Me}\right), 73.0\left(\mathrm{O}_{-} \mathrm{CH}_{2}\right), 73.4\left(\mathrm{O}-\mathrm{CH}_{2}\right), 88.1(\mathrm{C} 5), 93.8(\mathrm{C} 7)$, $106.6(\mathrm{C} 3), 114.3(\operatorname{aryl} \mathrm{C}), 125.4(\mathrm{C} 2), 138.0(\operatorname{aryl} \mathrm{C}), 153.2(\mathrm{C} 4), 157.9(\mathrm{C} 6), 162.0\left(\mathrm{CO}_{2} \mathrm{Me}\right)$, 205.5 (COMe), 207.0 (COMe); HRMS (+ESI): Found $m / z$ 342.0948, [M + Na] ${ }^{+}, \mathrm{C}_{16} \mathrm{H}_{17} \mathrm{NO}_{6} \mathrm{Na}$ requires 342.0936 .

Methyl 4,6-bis((3-oxobutan-2-yl)oxy)-1H-indole-2-carboxylate (30): The title compound was prepared as described in GP-1 from methyl 4,6-dihdroxyindole-2-carboxylate (17) (100.4 mg, $0.485 \mathrm{mmol}), 3$-chloro-2-butanone $(102.8 \mathrm{mg}, 0.97 \mathrm{mmol})$, potassium carbonate $(123.8 \mathrm{mg}$, $0.97 \mathrm{mmol})$ to give the product $(148.1 \mathrm{mg}, 88 \%)$ as a white solid; m.p. $166-168{ }^{\circ} \mathrm{C} ; \mathrm{IR}(\mathrm{KBr})$ : $v_{\max } 3309,2918,2846,2315,2112,1917,1683,1621,1584,1520,1438,1380,1280,1205,1160$, 1088, 991, 934, 811, 769, $685 \mathrm{~cm}^{-1}$; UV-vis $\left(\mathrm{CH}_{3} \mathrm{CN}\right): \lambda_{\max } 207 \mathrm{~nm}\left(\varepsilon 28,500 \mathrm{~cm}^{-1} \mathrm{M}^{-1}\right), 245$ (21,600), 305 (22,800); ${ }^{1} \mathrm{H}-\mathrm{NMR}\left(300 \mathrm{MHz}, \mathrm{CDCl}_{3}\right): \delta 1.52$ (d, J = $\left.6.9 \mathrm{~Hz}, 3 \mathrm{H}, \mathrm{CH}-\mathrm{Me}\right), 1.59$ $(\mathrm{d}, J=6.9 \mathrm{~Hz}, 3 \mathrm{H}, \mathrm{CH}-\mathrm{Me}), 2.16$ (s, 3H, COMe), 2.24 (s, 3H, COMe), $3.95\left(\mathrm{~s}, 3 \mathrm{H}, \mathrm{CO}_{2} \mathrm{Me}\right)$, $4.55(\mathrm{q}, J=6.9 \mathrm{~Hz}, 1 \mathrm{H}, \mathrm{CH}-\mathrm{Me}), 4.78(\mathrm{q}, J=6.9 \mathrm{~Hz}, 1 \mathrm{H}, \mathrm{CH}-\mathrm{Me}), 6.09$ (d, $J=1.8 \mathrm{~Hz}, 1 \mathrm{H}, \mathrm{H} 5)$ $6.32(\mathrm{~d}, J=1.8 \mathrm{~Hz}, 1 \mathrm{H}, \mathrm{H7}), 7.32(\mathrm{t}, J=1.1 \mathrm{~Hz}, 1 \mathrm{H}, \mathrm{H} 3), 8.85(\mathrm{bs}, 1 \mathrm{H}, \mathrm{NH}) ;{ }^{13} \mathrm{C}-\mathrm{NMR}(75.6$ $\left.\mathrm{MHz}, \mathrm{CDCl}_{3}\right)$ : $\delta 17.4(\mathrm{CH}-\mathrm{Me}), 17.6(\mathrm{CH}-\mathrm{Me}), 24.4(\mathrm{COMe}), 24.6(\mathrm{COMe}), 51.6\left(\mathrm{CO}_{2} \mathrm{Me}\right)$, 
79.9 (C5), 88.5 (C7), 94.5 (CH-Me), 94.6 (CH-Me), 109.2 (C3), 112.9 (aryl C), 125.3 (C2), 141.1 (aryl C), 153.2 (C4), 158.0 (C6), $162.3\left(\mathrm{CO}_{2} \mathrm{Me}\right), 202.6$ (COMe), 210.6 (COMe); HRMS (+ESI): Found $m / z$ 370.1260, $[\mathrm{M}+\mathrm{Na}]^{+}, \mathrm{C}_{18} \mathrm{H}_{21} \mathrm{NO}_{6} \mathrm{Na}$ requires 370.1267.

Methyl 8-methyl-4-(2-oxopropoxy)-1H-furo[2,3-g]indole-2-carboxylate (33): The title compound was prepared as described in GP-2 from methyl 4,6-bis(2-oxopropoxy)-1H-indole-2-carboxylate (29) $(82.9 \mathrm{mg}, 0.26 \mathrm{mmol})$ with trifluoroacetic acid (10 drops) in dichloromethane (10 $\mathrm{mL})$ to give the product $(11.7 \mathrm{mg}, 15 \%)$ as a white solid; m.p. $142-144{ }^{\circ} \mathrm{C}$; IR (KBr): $v_{\max } 3357$, 2916, 2848, 2340, 2120, 1927, 1700, 1635, 1560, 1506, 1435, 1355, 1280, 1149, 1093, 1050, 994, 940, 801, 770, $704 \mathrm{~cm}^{-1}$; UV-vis $\left(\mathrm{CH}_{3} \mathrm{CN}\right): \lambda_{\max } 208 \mathrm{~nm}\left(\varepsilon 16,600 \mathrm{~cm}^{-1} \mathrm{M}^{-1}\right), 261(40,200)$, $298(15,100) ;{ }^{1} \mathrm{H}-\mathrm{NMR}\left(300 \mathrm{MHz}, \mathrm{CDCl}_{3}\right): \delta 2.40,(\mathrm{~s}, 3 \mathrm{H}, \mathrm{COMe}), 2.52(\mathrm{~d}, J=1.3 \mathrm{~Hz}, 3 \mathrm{H}$, C-Me), 4.00 (s, 3H, CO $2 \mathrm{Me}), 4.70\left(\mathrm{~s}, 2 \mathrm{H}, \mathrm{CH}_{2}\right), 6.63$ (s, 1H, H5), 7.39 (q, J = $1.3 \mathrm{~Hz}, 1 \mathrm{H}$, H7), 7.52 (d, $J=2.2 \mathrm{~Hz}, 1 \mathrm{H}, \mathrm{H} 3), 9.14$ (bs, $1 \mathrm{H}, \mathrm{NH}) ;{ }^{13} \mathrm{C}-\mathrm{NMR}\left(75.6 \mathrm{MHz}, \mathrm{CDCl}_{3}\right): \delta 9.8$ (C-Me), 26.7 (COMe), $51.9\left(\mathrm{CO}_{2} \mathrm{Me}\right), 73.3\left(\mathrm{CH}_{2}\right), 88.7$ (C5), 107.7 (C3), 108.4 (aryl C), 114.3 (C8), 115.5 (aryl C), 124.9 (C2), 130.8 (aryl C), 139.6 (C7), 150.3 (C4), 155.3 (aryl C), 162.2 $\left(\mathrm{CO}_{2} \mathrm{Me}\right), 207.9$ (COMe); HRMS (+ESI): Found $m / z$ 324.0846, $[\mathrm{M}+\mathrm{Na}]^{+}, \mathrm{C}_{16} \mathrm{H}_{15} \mathrm{NO}_{5} \mathrm{Na}$ requires 324.0848 .

Methyl 3,6-dimethyl-7H-difuro[2,3-e:2',3'-g]indole-8-carboxylate (31): The title compound was prepared as described in GP-2 from methyl 4,6-bis(2-oxopropoxy)-1H-indole-2-carboxylate (29) (82.9 mg, $0.26 \mathrm{mmol})$ with trifluoroacetic acid (10 drops) in dichloromethane (10 mL) to give the product $(38.3 \mathrm{mg}, 52 \%)$ as a white solid; m.p. $182-184{ }^{\circ} \mathrm{C}$; IR (KBr): $v_{\max } 3292$, 2918, 2849, 2318, 2116, 1917, 1676, 1641, 1524, 1432, 1400, 1343, 1281, 1298, 1103, 990, 924, 875, 800, $688 \mathrm{~cm}^{-1}$; UV-vis $\left(\mathrm{CH}_{3} \mathrm{CN}\right): \lambda_{\max } 238 \mathrm{~nm}\left(\varepsilon 33,400 \mathrm{~cm}^{-1} \mathrm{M}^{-1}\right), 255(31,200), 299$ $(15,400) ;{ }^{1} \mathrm{H}-\mathrm{NMR}\left(300 \mathrm{MHz}, \mathrm{CDCl}_{3}\right): \delta 2.55(\mathrm{~d}, J=1.3 \mathrm{~Hz}, 3 \mathrm{H}, \mathrm{Me}), 2.57(\mathrm{~d}, J=1.3 \mathrm{~Hz}, 3 \mathrm{H}$, $\mathrm{Me}), 3.99$ (s, 3H, CO $2 \mathrm{Me}$ ), 7.43 (d, $J=1.3 \mathrm{~Hz}, 1 \mathrm{H}, \mathrm{H} 5), 7.48$ (d, J=1.3 Hz, 1H, H2), 7.55 (d, J = 2.1 Hz, 1H, H9), 9.20 (bs, 1H, NH), ${ }^{13} \mathrm{C}-\mathrm{NMR}\left(75.6 \mathrm{MHz}, \mathrm{CDCl}_{3}\right): 9.4(\mathrm{CH}-\mathrm{Me}), 9.9$ (CH-Me), $51.9\left(\mathrm{CO}_{2} \mathrm{Me}\right), 105.8$ (C3 and C6), 109.5 (C9), 110.0 (aryl C), 111.1 (aryl C), 114.3 (aryl C), 115.2 (aryl C), 124.9 (C8), 129.0 (aryl C), 139.1 (C5), 139.4 (C2), 147.8 (aryl C), 162.2 $\left(\mathrm{CO}_{2} \mathrm{Me}\right)$; HRMS (+ESI): Found $m / z$ 306.0733, $[\mathrm{M}+\mathrm{Na}]^{+}, \mathrm{C}_{16} \mathrm{H}_{13} \mathrm{NO}_{4} \mathrm{Na}$ requires 306.0737.

Methyl 7,8-dimethyl-4-((3-oxobutan-2-yl)oxy)-1H-furo[2,3-g]indole-2-carboxylate (34): The title compound was prepared as described in GP-2 from methyl 4,6-bis((3-oxobutan-2-yl)oxy)1H-indole-2-carboxylate (30) $(90.2 \mathrm{mg}, 0.26 \mathrm{mmol})$ with the catalytic amount of trifluoroacetic acid (10 drops) in dichloromethane $(10 \mathrm{~mL})$ to give the product $(18 \mathrm{mg}, 21 \%)$ as a white solid; m.p. $150-152{ }^{\circ} \mathrm{C}$; IR (KBr): $\nu_{\max } 3326,2921,2831,2338,2110,1907,1686,1628$, 1590, 1528, 1501, 1437, 1354, 1271, 1161, 1115, 994, 941, 795, 770, $747 \mathrm{~cm}^{-1}$; UV-vis $\left(\mathrm{CH}_{3} \mathrm{CN}\right)$ : $\lambda_{\max } 263 \mathrm{~nm}\left(\varepsilon 58,400 \mathrm{~cm}^{-1} \mathrm{M}^{-1}\right), 301(21,000) ;{ }^{1} \mathrm{H}-\mathrm{NMR}\left(300 \mathrm{MHz}, \mathrm{CDCl}_{3}\right): \delta 1.62(\mathrm{~d}$, $J=7.0 \mathrm{~Hz}, 3 \mathrm{H}, \mathrm{CH}-\mathrm{Me}$ ), 1.64 (s, 3H, COMe), 2.40 (s, 3H, C-Me), 2.42 (s, 3H, C-Me), 3.99 (s, $\left.3 \mathrm{H}, \mathrm{CO}_{2} \mathrm{Me}\right), 4.77$ (q, J = 7.0 Hz, 1H, CH-Me), 6.65 (s, 1H, H5), 7.49 (d, J = 2.2 Hz, 1H, H3), 9.02 (bs, $1 \mathrm{H}, \mathrm{NH}) ;{ }^{13} \mathrm{C}-\mathrm{NMR}\left(75.6 \mathrm{MHz} \mathrm{CDCl}_{3}\right)$ : 89.9 (C-Me), 11.5 (C-Me), 17.6 (CH-Me), 29.7 (CO-Me), 51.9 ( $\left.\mathrm{CO}_{2} \mathrm{Me}\right), 79.5$ (CH-Me), 89.1 (C5), 107.8 (C3), 108.2 (aryl C), 115.7 (C8), 122.7 (aryl C), 124.6 (C2), 131.3 (aryl C), 148.4 (C4), 149.0 (C7), 153.2 (aryl C), 162.8 $\left(\mathrm{CO}_{2} \mathrm{Me}\right), 210.6$ (CO-Me); HRMS (+ESI): Found $m / z$ 352.1154, $[\mathrm{M}+\mathrm{Na}]^{+}, \mathrm{C}_{18} \mathrm{H}_{19} \mathrm{NO}_{5} \mathrm{Na}$ requires 352.1161 .

Methyl 2,3,5,6-tetramethyl-7H-difuro[2,3-e:2',3'-g]indole-8-carboxylate (32): The title compound was prepared as described in GP-2 from methyl 4,6-bis((3-oxobutan-2-yl)oxy)-1H-indole-2carboxylate (30) $(90.2 \mathrm{mg}, 0.26 \mathrm{mmol})$ with trifluoroacetic acid (10 drops) in dichloromethane $(10 \mathrm{~mL})$ to give the product $(49.3 \mathrm{mg}, 61 \%)$ as a white solid; m.p. $226-228^{\circ} \mathrm{C}$; IR $(\mathrm{KBr}): v_{\max }$ $3329,2918,2864,2318,2105,1921,1680,1639,1528,1437,1368,1275,1298,1180,1080,998$, 945, 800, 749, $651 \mathrm{~cm}^{-1}$; UV-vis $\left(\mathrm{CH}_{3} \mathrm{CN}\right): \lambda_{\max } 238 \mathrm{~nm}\left(\varepsilon 33,600 \mathrm{~cm}^{-1} \mathrm{M}^{-1}\right), 259(30,600)$, $304(14,200) ;{ }^{1} \mathrm{H}-\mathrm{NMR}\left(300 \mathrm{MHz}, \mathrm{CDCl}_{3}\right): \delta 2.44$ (s, 3H, Me), 2.45 (s, 3H, Me), 2.46 (s, 3H, $\mathrm{Me}), 2.47$ (s, 3H, Me), 3.97 (s, 3H, CO $2 \mathrm{Me}), 7.49$ (d, J = 2.1 Hz, 1H, H9), 9.08 (bs, 1H, NH); ${ }^{13} \mathrm{C}-\mathrm{NMR}\left(75.6 \mathrm{MHz}, \mathrm{CDCl}_{3}\right)$ : $\delta 9.5$ (C-Me), $10.0(\mathrm{C}-\mathrm{Me}), 11.6(2 \times \mathrm{C}-\mathrm{Me}), 51.8\left(\mathrm{CO}_{2} \mathrm{Me}\right)$, 105.4 (C3 and C6), 108.6 (C9), 108.9 (aryl C), 110.2 (aryl C), 110.7 (aryl C), 110.7 (aryl C), 
124.6 (C8), 128.3 (aryl C), 146.5 (aryl C),147.7 (C2), 147.9 (C5), $162.4\left(\mathrm{CO}_{2} \mathrm{Me}\right)$; HRMS (+ESI): Found $m / z$ 312.1232, $[\mathrm{M}+\mathrm{H}]^{+}, \mathrm{C}_{18} \mathrm{H}_{18} \mathrm{NO}_{4}$ requires 312.1230.

Methyl 5,6-bis(2-oxopropoxy)-1H-indole-2-carboxylate (37): The title compound was prepared as described in GP-1 from methyl 5,6-dihdroxyindole-2-carboxylate (18) $(100.4 \mathrm{mg}, 0.485 \mathrm{mmol})$, chloroacetone $(88.4 \mathrm{mg}, 0.97 \mathrm{mmol})$, potassium carbonate $(123.8 \mathrm{mg}, 0.97 \mathrm{mmol})$ to give the product $(100.6 \mathrm{mg}, 65 \%)$ as a white solid; m.p. $138-140{ }^{\circ} \mathrm{C}$; $\mathrm{IR}(\mathrm{KBr}): v_{\max } 3326,2915,2849$, 2362, 2137, 1966, 1677, 1633, 1522, 1480, 1434, 1357, 1244, 1207, 1145, 1041, 991, 897, 842, 761, $676 \mathrm{~cm}^{-1}$; UV-vis $\left(\mathrm{CH}_{3} \mathrm{CN}\right): \lambda_{\max } 209 \mathrm{~nm}\left(\varepsilon 35,500 \mathrm{~cm}^{-1} \mathrm{M}^{-1}\right), 310(23,900) ;{ }^{1} \mathrm{H}-\mathrm{NMR}(300$ $\left.\mathrm{MHz}, \mathrm{CDCl}_{3}\right): \delta 2.36(\mathrm{~s}, 6 \mathrm{H}, 2 \times \mathrm{Me}), 3.95\left(\mathrm{~s}, 3 \mathrm{H}, \mathrm{CO}_{2} \mathrm{Me}\right), 4.59\left(\mathrm{~s}, 2 \mathrm{H}, \mathrm{CH}_{2}\right), 4.67(\mathrm{~s}, 2 \mathrm{H}$, $\left.\mathrm{CH}_{2}\right), 6.84(\mathrm{~d}, J=0.6 \mathrm{~Hz}, 1 \mathrm{H}, \mathrm{H} 4), 7.08(\mathrm{~s}, 1 \mathrm{H}, \mathrm{H} 3), 7.12(\mathrm{dd}, J=2.1,0.9 \mathrm{~Hz}, 1 \mathrm{H}, \mathrm{H} 7), 8.89$ (bs, $1 \mathrm{H}, \mathrm{NH}),{ }^{13} \mathrm{C}-\mathrm{NMR}\left(75.6 \mathrm{MHz}, \mathrm{CDCl}_{3}\right): \delta 26.6$ (CO-Me), 29.7 (CO-Me), $51.9\left(\mathrm{CO}_{2} \mathrm{Me}\right), 74.3$ $\left(\mathrm{CH}_{2}\right), 74.8\left(\mathrm{CH}_{2}\right), 98.3(\mathrm{C} 7), 106.5(\mathrm{C} 4), 108.5(\mathrm{C} 3), 121.5(\operatorname{aryl} \mathrm{C}), 126.8(\mathrm{C} 2), 132.3(\operatorname{aryl} \mathrm{C})$, 144.5 (C6), 148.3 (C5), 162.0 ( $\left.\mathrm{CO}_{2} \mathrm{Me}\right), 205.5$ (CO-Me), 205.8 (CO-Me); HRMS (+ESI): Found $\mathrm{m} / \mathrm{z} 342.0940,[\mathrm{M}+\mathrm{Na}]^{+}, \mathrm{C}_{16} \mathrm{H}_{17} \mathrm{NO}_{6} \mathrm{Na}$ requires 342.0948 .

Methyl 5,6-bis((3-oxobutan-2-yl)oxy)-1H-indole-2-carboxylate (38): The title compound was prepared as described in GP-1 from methyl 5,6-dihydroxyindole-2-carboxylate (18) (100.4 mg, $0.485 \mathrm{mmol})$, 3-chloro-2-butanone (102.8 $\mathrm{mg}, 0.97 \mathrm{mmol})$, potassium carbonate (123.8 $\mathrm{mg}$, $0.97 \mathrm{mmol})$ to give the product $(114.5 \mathrm{mg}, 68 \%)$ as a white solid; m.p. $120-122{ }^{\circ} \mathrm{C}$; $\mathrm{IR}(\mathrm{KBr})$ : $v_{\max } 3335,2917,2832,2359,2100,1895,1687,1597,1519,1468,1434,1350,1252,1208,1162$, 1082, 977, 919, 838, $755 \mathrm{~cm}^{-1}$; UV-vis $\left(\mathrm{CH}_{3} \mathrm{CN}\right): \lambda_{\max } 212 \mathrm{~nm}\left(\varepsilon 34,100 \mathrm{~cm}^{-1} \mathrm{M}^{-1}\right), 305$ $(22,400) ;{ }^{1} \mathrm{H}-\mathrm{NMR}\left(300 \mathrm{MHz}, \mathrm{CDCl}_{3}\right): \delta 1.51-1.57(\mathrm{~m}, 6 \mathrm{H}, 2 \times \mathrm{CH}-\mathrm{Me}), 2.27(\mathrm{~d}, J=1.8 \mathrm{~Hz}$, $3 \mathrm{H}, \mathrm{CO}-\mathrm{Me}), 2.31(\mathrm{~d}, J=1.8 \mathrm{~Hz}, 3 \mathrm{H}, \mathrm{CO}-\mathrm{Me}), 3.88\left(\mathrm{~s}, 3 \mathrm{H}, \mathrm{CO}_{2} \mathrm{Me}\right), 4.60-4.69(\mathrm{~m}, 2 \mathrm{H}$, $2 \times \mathrm{CH}-\mathrm{Me}), 6.59(\mathrm{~s}, 1 \mathrm{H}, \mathrm{H} 3), 7.09(\mathrm{q}, J=1.8 \mathrm{~Hz}, 1 \mathrm{H}, \mathrm{H7}), 7.24(\mathrm{q}, J=1.8 \mathrm{~Hz}, 1 \mathrm{H}, \mathrm{H} 4), 8.81$ (bs, $1 \mathrm{H}, \mathrm{NH}),{ }^{13} \mathrm{C}-\mathrm{NMR}\left(75.6 \mathrm{MHz}, \mathrm{CDCl}_{3}\right): \delta 17.5$ (CH-Me), 17.6 (CH-Me), 24.6 (CO-Me), 24.8 (CO-Me), 51.6 ( $\mathrm{CO}_{2} \mathrm{Me}$ ), 81.4 (C7), 96.5 (C4), 108.7 (CH-Me), 108.9 (CH-Me), 111.0 (C3), $120.2(\operatorname{aryl} \mathrm{C}), 126.6(\mathrm{C} 2), 135.2(\operatorname{aryl} \mathrm{C}), 144.6(\mathrm{C} 6), 148.5(\mathrm{C} 5), 162.3\left(\mathrm{CO}_{2} \mathrm{Me}\right), 202.7(2 \times$ CO-Me); HRMS (+ESI): Found $m / z$ 370.1254, $[\mathrm{M}+\mathrm{Na}]^{+}, \mathrm{C}_{18} \mathrm{H}_{21} \mathrm{NO}_{6} \mathrm{Na}$ requires 370.1261.

Methyl 5-hydroxy-6-(2-oxopropoxy)-1H-indole-2-carboxylate (41): The title compound was prepared as described in GP-1 from methyl 5,6-dihydroxyindole-2-carboxylate (18) (100.4 mg, $0.485 \mathrm{mmol})$, chloroacetone $(88.4 \mathrm{mg}, 0.97 \mathrm{mmol})$, potassium carbonate $(123.8 \mathrm{mg}, 0.97 \mathrm{mmol})$ to give the product ( $35.7 \mathrm{mg}, 28 \%$ ) as a white solid; m.p. $182-184{ }^{\circ} \mathrm{C}$; IR (KBr): $v_{\max } 3334$, 2918, 2855, 2318, 2106, 1948, 1682, 1622, 1519, 1486, 1430, 1351, 1248, 1203, 995, 920, 826, 799, $749,694 \mathrm{~cm}^{-1}$; UV-vis $\left(\mathrm{CH}_{3} \mathrm{CN}\right): \lambda_{\max } 238 \mathrm{~nm}\left(\varepsilon 37,500 \mathrm{~cm}^{-1} \mathrm{M}^{-1}\right), 259(23,200),{ }_{i}^{1} \mathrm{H}-\mathrm{NMR}$ $\left(300 \mathrm{MHz}, \mathrm{CDCl}_{3}\right): \delta 2.37$ (s, 3H, Me), $3.90\left(\mathrm{~s}, 3 \mathrm{H}, \mathrm{CO}_{2} \mathrm{Me}\right), 4.67\left(\mathrm{~s}, 2 \mathrm{H}, \mathrm{CH}_{2}\right), 5.26$ (bs, $1 \mathrm{H}$, $\mathrm{OH}), 6.62(\mathrm{~s}, 1 \mathrm{H}, \mathrm{H} 7), 7.09$ (s, 1H, H4), 7.27 (d, $J=1.8 \mathrm{~Hz} .1 \mathrm{H}, \mathrm{H} 3), 8.85$ (bs, $1 \mathrm{H}, \mathrm{NH})$; ${ }^{13} \mathrm{C}-\mathrm{NMR}\left(75.6 \mathrm{MHz}, \mathrm{CDCl}_{3}\right): \delta 23.4(\mathrm{CO}-\mathrm{Me}), 50.8\left(\mathrm{CO}_{2} \mathrm{Me}\right), 70.1\left(\mathrm{CH}_{2}\right), 92.8$ (aryl C), 98.1 (C7), 107.5 (C4), 107.6 (C3), 122.1 (aryl C), 126.9 (C2), 138.7 (C5), 142.9 (C6), 161.6 $\left(\mathrm{CO}_{2} \mathrm{Me}\right), 204.9$ (CO-Me); HRMS (+ESI): Found $\mathrm{m} / z$ 286.0684, [M + Na $]^{+}, \mathrm{C}_{13} \mathrm{H}_{13} \mathrm{NO}_{5} \mathrm{Na}$ requires 286.0691 .

Methyl 5-hydroxy-6-((3-oxobutan-2-yl)oxy)-1H-indole-2-carboxylate (42): The title compound was prepared as described in GP-1 from methyl 5,6-dihydroxyindole-2-carboxylate (18) (100.4 mg, $0.485 \mathrm{mmol}), 3$-chloro-2-butanone (102.8 mg, $0.97 \mathrm{mmol})$, potassium carbonate (123.8 mg, $0.97 \mathrm{mmol})$ to give the product $(43.0 \mathrm{mg}, 32 \%)$ as a white solid; m.p. $198-200{ }^{\circ} \mathrm{C}$; IR (KBr): $v_{\max } 3379,2987,2943,2343,2107,1946,1694,1618,1523,1439,1379,1294,1238$, 1144, 1069, 928, 857, 760, $726 \mathrm{~cm}^{-1}$; UV-vis $\left(\mathrm{CH}_{3} \mathrm{CN}\right): \lambda_{\max } 209 \mathrm{~nm}\left(\varepsilon 40,300 \mathrm{~cm}^{-1} \mathrm{M}^{-1}\right)$, 319 (27,500); ${ }^{1} \mathrm{H}-\mathrm{NMR}\left(300 \mathrm{MHz}, \mathrm{CDCl}_{3}\right): \delta 1.45$ (d, J = 2.1 Hz, 3H, CH-Me), 2.89 (s, 3H, C-Me), 3.87 (s, 3H, CO $2 \mathrm{Me}), 4.02-4.09(\mathrm{~m}, 1 \mathrm{H}, \mathrm{CH}-\mathrm{Me}), 5.61$ (bs, 1H, OH), 6.97 (dd, J = 2.1, $0.9 \mathrm{~Hz}, 1 \mathrm{H}, \mathrm{H} 7), 7.03(\mathrm{q}, J=1.3 \mathrm{~Hz}, 1 \mathrm{H}, \mathrm{H} 3), 7.04(\mathrm{~s}, 1 \mathrm{H}, \mathrm{H} 4), 10.57(\mathrm{bs}, 1 \mathrm{H}, \mathrm{NH}),{ }^{13} \mathrm{C}-\mathrm{NMR}$ (75.6 MHz, $\left.\mathrm{CDCl}_{3}\right)$ : $\delta 15.2(\mathrm{CH}-\mathrm{Me}), 23.6(\mathrm{CO}-\mathrm{Me}), 50.8\left(\mathrm{CO}_{2} \mathrm{Me}\right), 94.6(\mathrm{CH}-\mathrm{Me}), 97.8(\mathrm{C} 7)$, 107.2 (C4), 107.5 (C3), 121.9 (aryl C), 126.7 (C2), 133.5 (aryl C), 138.9 (C6), 144.0 (C5), 161.6 $\left(\mathrm{CO}_{2} \mathrm{Me}\right), 205.3$ (CO-Me); HRMS (+ESI): Found $m / z$ 300.0846, $[\mathrm{M}+\mathrm{Na}]^{+}, \mathrm{C}_{14} \mathrm{H}_{15} \mathrm{NO}_{5} \mathrm{Na}$ requires 300.0842 . 
Methyl 5-hydroxy-7,8-dimethyl-4-(2,2,2-trifluoroacetyl)-1H-furo[2,3-g]indole-2-carboxylate (43): The title compound was prepared as described in GP-2 from methyl 5-hydroxy-6-((3oxobutan-2-yl)oxy)- $1 H$-indole-2-carboxylate (42) $(72.6 \mathrm{mg}, 0.26 \mathrm{mmol})$ with 1:1 DCM:TFA $(10 \mathrm{~mL})$ to give the product $(59.1 \mathrm{mg}, 64 \%)$ as a yellow solid; m.p. $224-226^{\circ} \mathrm{C}$; IR $(\mathrm{KBr})$ : $v_{\max } 3369,2972,2845,2330,2122,1902,1700,1635,1601,1521,1429,1288,1238,1135,1075$, 927, 874, 790, $760 \mathrm{~cm}^{-1}$; UV-vis $\left(\mathrm{CH}_{3} \mathrm{CN}\right): \lambda_{\max } 235 \mathrm{~nm}\left(\varepsilon 26,600 \mathrm{~cm}^{-1} \mathrm{M}^{-1}\right), 272(23,100)$, $381(31,000) ;{ }^{1} \mathrm{H}-\mathrm{NMR}\left(300 \mathrm{MHz}, \mathrm{CDCl}_{3}\right): \delta 2.55(\mathrm{~d}, J=1.8 \mathrm{~Hz}, 3 \mathrm{H}, \mathrm{Me}), 2.47(\mathrm{~d}, J=1.8 \mathrm{~Hz}$, $3 \mathrm{H}, \mathrm{Me}), 4.01\left(\mathrm{~s}, 3 \mathrm{H}, \mathrm{CO}_{2} \mathrm{Me}\right), 7.59(\mathrm{t}, J=1.8 \mathrm{~Hz}, 1 \mathrm{H}, \mathrm{H} 3), 9.27(\mathrm{bs}, 1 \mathrm{H}, \mathrm{NH}), 13.44(\mathrm{bs}, 1 \mathrm{H}$, $\mathrm{OH}),{ }^{13} \mathrm{C}-\mathrm{NMR}\left(75.6 \mathrm{MHz}, \mathrm{CDCl}_{3}\right): \delta 9.6(\mathrm{C}-\mathrm{Me}), 12.3(\mathrm{C}-\mathrm{Me}), 52.2\left(\mathrm{CO}_{2} \mathrm{Me}\right), 102.7(\mathrm{C} 4)$, $109.7(\mathrm{C} 3), 109.8,(\mathrm{C} 8), 110.7\left(\mathrm{CF}_{3}\right) 118.6(\operatorname{aryl} \mathrm{C}), 124.1(\mathrm{C} 2), 126.3(\operatorname{aryl} \mathrm{C}), 126.6(\operatorname{aryl} \mathrm{C})$, 140.8 (C5), 153.5 ( $\operatorname{aryl} \mathrm{C}), 157.7$ (C7), $161.9\left(\mathrm{CO}_{2} \mathrm{Me}\right), 181.9\left(\mathrm{CO}^{-C_{3}}\right)$; HRMS (+ESI): Found $\mathrm{m} / \mathrm{z}$ 378.0568, $[\mathrm{M}+\mathrm{Na}]^{+}, \mathrm{C}_{16} \mathrm{H}_{12} \mathrm{~F}_{3} \mathrm{NO}_{5} \mathrm{Na}$ requires 378.0565.

\subsection{Cell Biology Techniques}

The SH-SY5Y and Kelly human neuroblastoma cell lines were generously donated by Dr. J. Biedler (Memorial Sloan-Kettering Cancer Center, New York, NY, USA). The MDA-MB-231 and MCF-7 breast cancer cell lines were purchased from the American Type Culture Collection. All cell lines were cultured under standard conditions at $37^{\circ} \mathrm{C}$ in $5 \%$ $\mathrm{CO}_{2}$ as an adherent monolayer in Dulbecco's modified Eagle's medium supplemented with L-glutamine (DMEM) (Invitrogen, Waltham, MA, USA) and 10\% foetal calf serum (FCS) (Thermo Fisher Scientific, Waltham, MA, USA).

\subsection{Method for Cell Viability Assays}

Cell viability was measured by the standard Alamar blue assay, as previously described [14]. Briefly, cells were allowed to attach for $24 \mathrm{~h}$ in 96-well culture plates. The cells were then continuously exposed to serial dilutions of the hydrazide-hydrazone derivatives for $72 \mathrm{~h}$, either in the presence or absence of SAHA $(0.5$ or $1 \mu \mathrm{M})$, with five replicate wells for each determination. Cell viability was determined by the addition of $22 \mu \mathrm{L}$ of Alamar blue reagent, recorded at comparative $0 \mathrm{~h}$ and $5 \mathrm{~h}$ values, using a Wallac 1420 Victor III spectrophotometer (GMI, Ramsey, MN, USA), which measured light absorbance in each well at $570 \mathrm{~nm}$. The cell viability of each plate was calculated as a percentage compared to matched DMSO controls $(0.5 \%)$. The mean $(+/-\mathrm{SEM})$ is shown for three independent experiments.

\subsection{Statistical Analysis}

Results of the cell viability studies were statistically analysed using the two-tailed, unpaired Student's $t$-test. Results are expressed as mean values with $95 \%$ confidence intervals.

\section{Conclusions}

In this manuscript, methyl 4,6-dihydroxyindole (17), 5,6-dihydroxyindole (18), 5hydroxy-6-methoxyindoles-2-carboxylate (19) and 6-hydroxy-5-methoxy-2-carboxylate (20) were used to generate new classes of tetracyclic and tricyclic furoindole systems. Tricyclic furo[3,2-e]indoles and furo[2,3-g]indoles were readily prepared by the treatment of the corresponding monohydroxyindoles 19 and 20 with $\alpha$-haloketones followed by the cyclization with a catalytic amount of acid. Methyl 4,6-dihydroxyindole-2-carboxylate 17 afforded the di-alkylated systems as the only products upon alkylation, while in the case of methyl 5,6-dihydroxyindole-2-carboxylate 18, the hydroxyl group at the $\mathrm{C} 6$ was more reactive than the one at $\mathrm{C} 5$, generating the $\mathrm{O}-\mathrm{C} 6$ monoalkylated intermediates as minor products, with higher yields of di-alkylated intermediates also formed. However, while the desired tetracyclic furoindoles could be generated by the treatment of intermediates derived from 4,6-dihydroxyindole 17, attempts failed to produce the desired tricyclic and tetracyclic products from the 5,6-dihydroxyindole 18 system. Presumably the cyclization reaction of $\mathbf{4 2}$ gives the intermediate benzofuran product which is able to generate the unexpected tricyclic furoindole $\mathbf{4 3}$ containing a trifluoroacetyl group at the $\mathrm{C} 4$ position. 
Biological studies revealed that the furoindole systems showed moderate cytotoxicity towards neuroblastoma and breast cancer cells. However, compound $\mathbf{4 3}$ was the only product which could be considered as a promising SAHA enhancer with $29 \%$ additional reduction of SH-SY5Y viability compared to SAHA alone. It was also interesting to note that the non-cyclized intermediate compound $\mathbf{3 0}$ displayed a strong cytotoxicity with $\mathrm{IC}_{50}$ values of 13.3 and $3.1 \mu \mathrm{M}$ against the SH-SY5Y and Kelly neuroblastoma cell lines, and was even more potent than its corresponding mono-cyclized (34) and di-cyclized (32) analogues.

Author Contributions: N.K., D.S.B. and B.B.C. conceived and designed the experiments, G.M.A. provided the data from library screening, M.B. performed the experiments, analysed, interpreted the data and wrote the paper, N.K. and G.M.M. supported financially. All authors have read and agreed to the published version of the manuscript.

Funding: This research was funded by Australian Postgraduate Research Scholarships, UNSW Sydney, Program Grants from the NHMRC Australia (APP1016699), Cancer Institute NSW Australia (10/TPG/1-13) and Cancer Council NSW Australia (PG-11-06) to GMM and BBC. This work was also funded by the Steven Walter Children's Cancer Foundation, NHMRC (Project Grant APP1125171) and Neuroblastoma Australia (GMM, BBC); the Children's Cancer Institute Australia for Medical Research is affiliated with the University of NSW and Sydney Children's Hospital.

Institutional Review Board Statement: Not applicable.

Informed Consent Statement: Not applicable.

Data Availability Statement: Data are contained within the article and the figures in Supporting materials.

Acknowledgments: We thank UNSW Sydney, and the Australian Research Council (ARC) for funding to N.K. and D.S.B. Mass spectrometric analysis for this work, which was carried out at the Bioanalytical Mass Spectrometry Facility.

Conflicts of Interest: The authors declare no conflict of interest.

Sample Availability: Samples of the compounds are available from the authors.

\section{References}

1. Mann, B.S.; Johnson, J.R.; He, K.; Sridhara, R.; Abraham, S.; Booth, B.P.; Verbois, L.; Morse, D.E.; Jee, J.M.; Pope, S.; et al. Vorinostat for treatment of cutaneous manifestations of advanced primary cutaneous T-cell lymphoma. Clin. Cancer Res. 2007, 13, $2318-2322$. [CrossRef]

2. Kelly, W.K.; O'Connor, O.A.; Krug, L.M.; Chiao, J.H.; Heaney, M.; Curley, T.; MacGregore-Cortelli, B.; Tong, W.; Secrist, J.P.; Schwartz, L.; et al. Phase I study of an oral histone deacetylase inhibitor, suberoylanilide hydroxamic acid, in patients with advanced cancer. J. Clin. Oncol. 2005, 23, 3923-3931. [CrossRef]

3. Krug, L.M.; Curley, T.; Schwartz, L.; Richardson, S.; Marks, P.; Chiao, J.; Kelly, W.K. Potential role of histone deacetylase inhibitors in mesothelioma: Clinical experience with suberoylanilide hydroxamic acid. Clin. Lung Cancer 2006, 7, 257-261. [CrossRef]

4. Coffey, D.C.; Kutko, M.C.; Glick, R.D.; Butler, L.M.; Heller, G.; Rifkind, R.A.; Marks, P.A.; Richon, V.M.; La Quaglia, M.P. The histone deacetylase inhibitor, CBHA, inhibits growth of human neuroblastoma xenogarfts in vivo alone and synergistically with all-trans retinoic acid. Cancer Res. 2001, 61, 3591-3594. [PubMed]

5. Jaboin, J.; Wild, J.; Hamidi, H.; Khanna, C.; Kim, C.J.; Robey, R.; Bates, S.E.; Thiele, C.J. MS-27-275, an inhibitor of histone deacetylase, has marked in vitro and in vivo antitumor activity against pediatric solid tumors. Cancer Res. 2002, 62, 6108-6115. [PubMed]

6. Basu, H.S.; Mahlum, A.; Mehraein-Ghomi, F.; Kegel, S.J.; Guo, S.; Peters, N.R.; Wilding, G. Pretreatment with anti-oxidants sensitizes oxidatively stressed human cancer cells to growth inhibitory effect of suberoylanilide hydroxamic acid (SAHA). Cancer Chemother. Pharmacol. 2011, 67, 705-715. [CrossRef] [PubMed]

7. Richon, V.M. Cancer biology: Mechanism of antitumour action of vorinostat (suberoylanilide hydroxamic acid), a novel histone deacetylase inhibitor. Br. J. Cancer 2006, 95, 2-6. [CrossRef]

8. Duvic, M.; Zhang, C. Clinical and laboratory experience of vorinostat (suberoylanilide hydroxamic acid) in the treatment of cutaneous T-cell lymphoma. Br. J. Cancer 2006, 95, 13-19. [CrossRef]

9. Rundall, B.K.; Denlinger, C.E.; Jones, D.R. Suberoylanilide hydroxamic acid combined with gemcitabine enhances apoptosis in non-small cell lung cancer. Surgery 2005, 138, 360-367. [CrossRef]

10. Sonnemann, J.; Gange, J.; Kumar, K.S.; Muller, C.; Bader, P.; Beck, J.F. Histone deacetylase inhibitors interact synergistically with tumor necrosis factor-related apoptosis-inducing ligand (TRAIL) to induce apoptosis in carcinoma cell lines. Investig. New Drug 2005, 23, 99-109. [CrossRef] [PubMed] 
11. Denlinger, C.E.; Rundall, B.K.; Jones, D.R. Proteasome inhibition sensitizes non-small cell lung cancer to histone deacetylase inhibitor-induced apoptosis through the generation of reactive oxygen species. J. Thorac. Cardiovasc. Surg. 2004, 128, 740-748. [CrossRef]

12. Cheung, B.B.; Kleynhans, A.; Mittra, R.; Kim, P.Y.; Holien, J.K.; Nagy, Z.; Ciampa, O.C.; Seneviratne, J.A.; Mayoh, C.; Raipuria, M.; et al. A novel combination therapy targeting ubiquitin-specific protease 5 in MYCN-driven neuroblastoma. Oncogene 2021, 40, 2367-2381. [CrossRef]

13. Bingul, M.; Arndt, G.M.; Marshall, G.M.; Cheung, B.B.; Kumar, N.; Black, D.S. Synthesis, characterization and biological evaluation of novel dihydropyranoindoles improving the anticancer effects of HDAC inhibitors. Molecules 2020, $25,1377$. [CrossRef] [PubMed]

14. Marks, P. Discovery and development of SAHA as an anticancer agent. Oncogene 2007, 26, 1351-1356. [CrossRef]

15. Hemetsberger, H.; Knittel, D.; Weidmann, H. Synthese und thermolyse von $\alpha$-azidoacrylestern. Chem. Mon. 1972, 103, 194-204. [CrossRef]

16. Borza, I.; Bozo, E.; Barta-Szalai, G.; Kiss, C.; Tarkanyi, G.; Demeter, A.; Gati, T.; Hada, V.; Kolok, S.; Gere, A.; et al. Selective NR1/2B N-Methyl-D-aspartate receptor antagonists among indole-2-carboxamides and benzimidazole-2-carboxamides. J. Med. Chem. 2007, 50, 901-914. [CrossRef]

17. McElhanon, J.R.; Wu, M.J.; Escobar, M.; Chaudhry, U.; Hu, C.L.; McGrath, D.V. Asymmetric synthesis of a series of chiral AB2 monomers for dendrimer construction. J. Org. Chem. 1997, 62, 908-915. [CrossRef]

18. Robinson, R.; Rugasava, S. CCCCXXXVIII.-Preliminary synthetical experiments in the morphine group. Part, I. J. Chem. Soc. 1931, 3163-3172. [CrossRef]

19. Meyers, A.I.; Guiles, J. The asymmetric total synthesis of (+)-Reticuline. Heterocycles 1989, 28, 295-301. [CrossRef]

20. Okano, K.; Tokuyama, H.; Fukuyama, T. Total synthesis of (+)-Yatakemycin. J. Am. Chem. Soc. 2006, 128, 7136-7137. [CrossRef] [PubMed]

21. Tsotinis, A.; Gerasimopoulou, M.; Vlachou, M.; Moreau, D.; Roussakis, C. C5,C6-Disubstituted 1H-indole-2-carboxamides: Synthesis and cytotoxic activity in the human non-small lung cancer cell line NSCLC-N16-L16. Lett. Drug Des. Discov. 2006, 3, 14-16. [CrossRef]

22. Li, Z.J.X.; Xue, S.; Tao, P.; Wang, Z. Substituted Benzoheterocyclic Compounds and Preparation Method and Application Thereof. CN 102952062A, 6 March 2013.

23. Wilcox, M.E.; Wyler, H.; Mabry, T.J.; Dreiding, A.S. Die Struktur des Betanins. 7. Mitteilung. Über die Konstitution des Randenfarbstoffes Betanin. Helv. Chim. Acta 1965, 48, 252-258. [CrossRef]

24. Stanislav, P.; Frits, A.J.M. Synthesis of deuterium labeled eumelanine (precursor) metabolites. J. Label. Compd. Radiopharm. 1983, 1, 101-110.

25. An, S.-Y.; Zhang, J.-L.; Jiang, G.-X. Synthesis of tetraphenyl-furoindoles via tandem reactions. Heterocycles 2021, 102, 1517-1522.

26. Black, D.S.; Bowyer, M.C.; Catalano, M.M.; Ivory, A.J.; Keller, P.A.; Kumar, N.; Nugent, S.J. Substitution, oxidation and addition reactions at C-7 of activated indoles. Tetrahedron 1994, 50, 10497-10508. [CrossRef] 